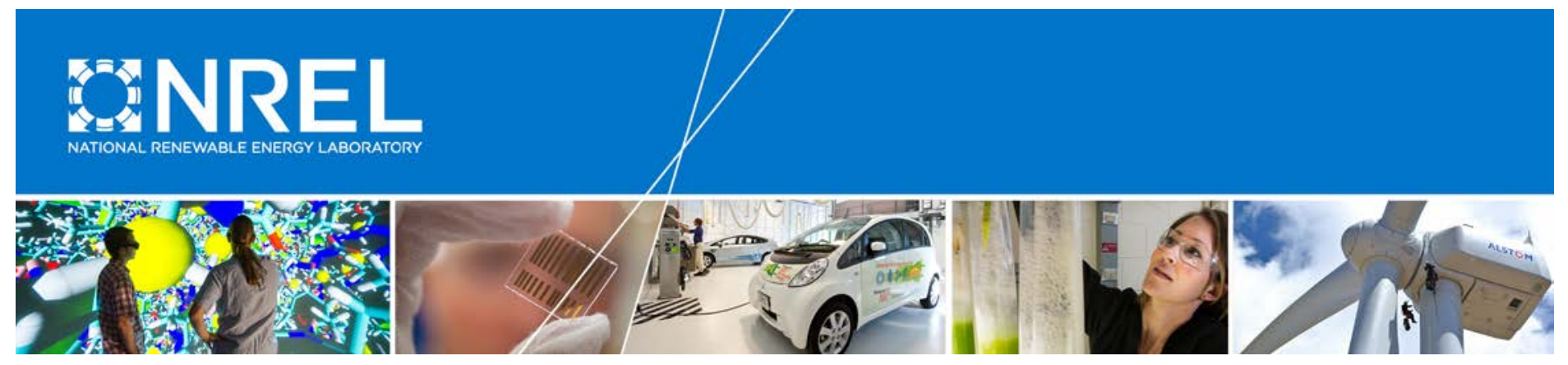

\title{
Wind Energy Finance in the United States: Current Practice and Opportunities
}

Paul Schwabe, David Feldman, Jason Fields, and Edward Settle

National Renewable Energy Laboratory

NREL is a national laboratory of the U.S. Department of Energy Office of Energy Efficiency \& Renewable Energy Operated by the Alliance for Sustainable Energy, LLC

This report is available at no cost from the National Renewable Energy Laboratory (NREL) at www.nrel.gov/publications.

Technical Report

NREL/TP-6A20-68227

August 2017

Contract No. DE-AC36-08GO28308 


\section{Wind Energy Finance in the United States: Current Practice and Opportunities}

Paul Schwabe, David Feldman, Jason Fields, and Edward Settle National Renewable Energy Laboratory

Prepared under Task No. WE16.3H01

NREL is a national laboratory of the U.S. Department of Energy Office of Energy Efficiency \& Renewable Energy Operated by the Alliance for Sustainable Energy, LLC

This report is available at no cost from the National Renewable Energy Laboratory (NREL) at www.nrel.gov/publications.

National Renewable Energy Laboratory 15013 Denver West Parkway Golden, CO 80401

303-275-3000 • www.nrel.gov

\section{Technical Report}

NREL/TP-6A20-68227

August 2017

Contract No. DE-AC36-08GO28308 


\section{NOTICE}

This report was prepared as an account of work sponsored by an agency of the United States government. Neither the United States government nor any agency thereof, nor any of their employees, makes any warranty, express or implied, or assumes any legal liability or responsibility for the accuracy, completeness, or usefulness of any information, apparatus, product, or process disclosed, or represents that its use would not infringe privately owned rights. Reference herein to any specific commercial product, process, or service by trade name, trademark, manufacturer, or otherwise does not necessarily constitute or imply its endorsement, recommendation, or favoring by the United States government or any agency thereof. The views and opinions of authors expressed herein do not necessarily state or reflect those of the United States government or any agency thereof.

This report is available at no cost from the National Renewable Energy Laboratory (NREL) at www.nrel.gov/publications.

Available electronically at SciTech Connect http:/www.osti.gov/scitech

Available for a processing fee to U.S. Department of Energy and its contractors, in paper, from:

U.S. Department of Energy Office of Scientific and Technical Information

P.O. Box 62

Oak Ridge, TN 37831-0062

OSTI http://www.osti.gov

Phone: 865.576.8401

Fax: 865.576.5728

Email: reports@osti.gov

Available for sale to the public, in paper, from:

U.S. Department of Commerce

National Technical Information Service

5301 Shawnee Road

Alexandria, VA 22312

NTIS http://www.ntis.gov

Phone: 800.553 .6847 or 703.605 .6000

Fax: 703.605.6900

Email: orders@ntis.gov 


\section{Acknowledgments}

This work was supported by the U.S. Department of Energy under Contract No. DE-AC3608GO28308 with Alliance for Sustainable Energy, LLC, the Manager and Operator of the National Renewable Energy Laboratory. Funding for the work was provided by the DOE Office of Energy Efficiency and Renewable Energy, Wind and Water Power Technologies Office. We wish to thank the following individuals who reviewed and provided insightful feedback to earlier versions of this report: Audun Botterud, Argonne National Laboratory; Dave James and Christopher Schneider, CoBank; Matt McCabe, Clear Wind; and Lori Bird, Jaquelin Cochran, Jenny Heeter, and Eric Lantz, National Renewable Energy Laboratory. We would like to also thank Karin Haas and Kathryn Ruckman and for their editorial assistance. 


\section{List of Acronyms}

$\begin{array}{ll}\text { A2e } & \text { Atmosphere to Electrons } \\ \text { DOE } & \text { Department of Energy } \\ \text { DSCR } & \text { debt service coverage ratio } \\ \text { FTR } & \text { financial transmission rate } \\ \text { gigawatt } \\ \text { GW } & \text { Internal Rate of Return } \\ \text { IRR } & \text { Internal Revenue Service } \\ \text { IRS } & \text { investment tax credit } \\ \text { ITC } & \text { kilowatt-hour } \\ \text { kWh } & \text { levelized cost of energy } \\ \text { LCOE } & \text { limited liability company } \\ \text { LLC } & \text { limited liability partnership } \\ \text { LLP } & \text { modified accelerated cost recovery system } \\ \text { MACRS } & \text { megawatt } \\ \text { MW } & \text { megawatt-hour } \\ \text { MWh } & \text { National Renewable Energy Laboratory } \\ \text { NREL } & \text { operations and maintenance } \\ \text { O\&M } & \text { power purchase agreement } \\ \text { PPA } & \text { performance, risk, uncertainty, and finance } \\ \text { PRUF } & \text { production tax credit } \\ \text { PTC } & \text { photovoltaic } \\ \text { PV } & \text { renewable portfolio standard } \\ \text { RPS } & \text { special purpose vehicle } \\ \text { SPV } & \text { system advisor model } \\ \text { SAM } & \text { Weighted Average Cost of Capital } \\ \text { WACC } & \end{array}$

iv 


\section{Executive Summary}

In the United States, investment in wind energy has averaged nearly \$13.6 billion annually since 2006 with more than $\$ 140$ billion invested cumulatively over that period (BNEF 2017). This sizable investment activity demonstrates the persistent appeal of wind energy and its increasing role in the U.S electricity generation portfolio. Despite its steady investment levels over the last decade, some investors still consider wind energy as a specialized asset class. Limited familiarity with the asset class both limit the pool of potential investors and drive up costs for investors.

This publication provides an overview of the wind project development process, capital sources and financing structures commonly used, and traditional and emerging procurement methods. It also provides a high-level demonstration of how financing rates impact a project's all-in cost of energy. The goal of the publication is to provide a representative and wide-ranging resource for the wind development and financing processes.

Wind energy finance generally comprises three main sources of capital: sponsor equity, tax equity, and debt. The blend and proportion of each of these capital sources in a given project is referred to as the capital structure or capital stack. Each source is discussed briefly below:

- Sponsor equity in a project most closely resembles a traditional equity investor and often can be provided by the original developer of the project. The sponsor equity is typically the first investor to suffer losses and the last to receive distributions of profit. Because the sponsor commonly faces the highest risk in the partnership, it will often have the highest return requirements, but is typically a small portion of the overall capital stack.

- Tax equity will commit upfront capital to a project in exchange for access to tax credits and tax losses from accelerated depreciation. Because this type of investment requires significant capital and tax capacity for up to ten years, tax equity investors are often large financial entities such as banks and insurance funds. Tax equity investors have several other tax-oriented investment options outside of wind to consider including solar energy as well as affordable housing.

- Debt capital is a contractually-arranged loan that must be repaid by the borrower and occurs when the lender has no ownership shares in the company or venture. Debt is generally a lower-risk and lower-cost funding source relative to equity-particularly as compared to sponsor equity. Debt capital providers benefit from additional financing protections such as contractually-fixed payment schedules, preferred repayment positions, access to collateral, and rights to assume control of a defaulting company if necessary. Debt capital may be invested through a variety of different financial mechanisms including a construction loan, a direct loan to the sponsor or developer of the project, or, to a lesser extent, a loan to the project itself.

One of the key factors in wind finance is the mechanism by which electricity is sold.

Traditionally, power purchase agreements (PPAs) have been used as a contract between energy generators (sellers) and energy "offtakers" (buyers). Offtakers generally include utilities and other load-serving entities; increasingly, however, corporate buyers and financial companies are also serving as offtakers. Wiser and Bolinger (2016) report that around $24 \%$ of cumulative installed wind projects have been constructed on a "merchant/quasi-merchant" basis in which they are financed and built with either a partial PPA or without a PPA entirely, instead selling 
energy into the wholesale spot markets, typically with a pricing hedge contract. In these cases, investors may demand a higher return for the risks attendant to merchant projects, such as unforeseen shortfalls in revenue and resource risk (Wiser and Bolinger 2016). Recently, the various procurement strategies by which corporations have sought to supplement their electricity purchases with wind contracts have included offsite PPAs, virtual PPAs, and other mechanisms.

This report also provides a high-level illustrative example of how financing rates can modestly impact a project's overall cost of energy and, accordingly, its cost competitiveness with other investment alternatives. The financing rates of a wind project reflect the perceived risks by potential investors in a project. These risks can be categorized into three basic risk types. General risks can be attributed to macroeconomic forces and market-wide risks tolerances, which are illustrated in metrics such as benchmark interest rates. There are also wind-industryspecific risks derived from issues like regional market factors, national incentive structures, and industry-wide financing practices. Lastly, there are many wind-project-specific risks such as the turbine's performance history in the marketplace, the project developer's history of delivering projects on time and budget, the use of contractual elements to mitigate risks, and other subjective factors. All of these considerations contribute to both the ability of the developer to secure financing as well as the overall investment costs for a wind energy project.

Looking ahead, the near-term outlook for wind energy reported previously suggests a continued need for capital at levels consistent with deployment seen in 2015 and 2016 (Wiser and Bolinger 2016). The market has shown the capacity to finance projects using the current mechanisms at economically viable rates; however, increased deployment could require investment from new capital providers. Broad changes to the financial industry - such as the possibility of major corporate tax reform and, specifically, the role of the tax equity - could fundamentally reshape the predominant mechanism for wind energy investment. Financing will continue to have at least a modest impact on a project's overall economic competitiveness, and efforts to open up more capital sources and reduce financing costs will be one of a set of levers to improve the economic competitiveness of wind power and enable a larger expansion onto the power grid. 


\section{Table of Contents}

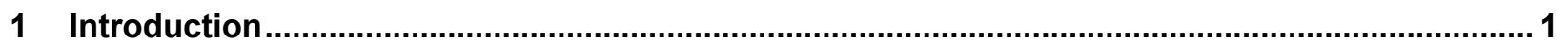

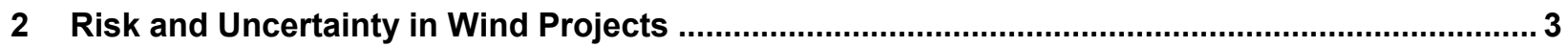

3 Wind Energy Project Lifecycle ................................................................................................ 6

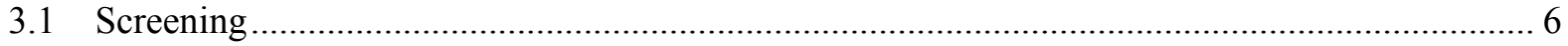

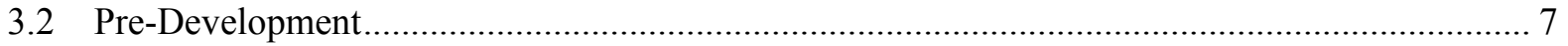

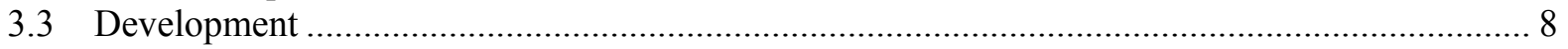

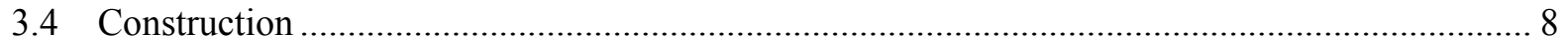

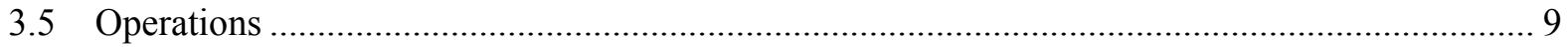

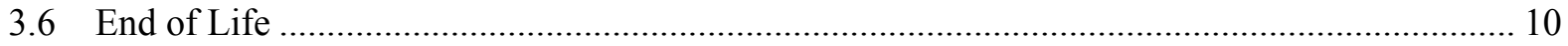

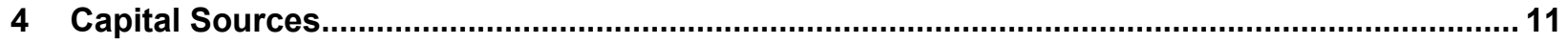

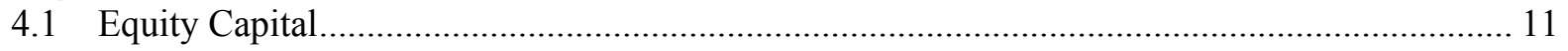

4.1.1 U.S. Federal Tax Incentives ......................................................................... 11

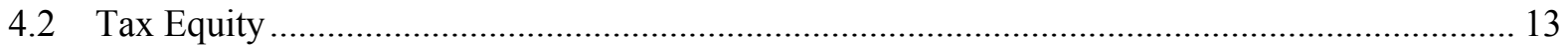

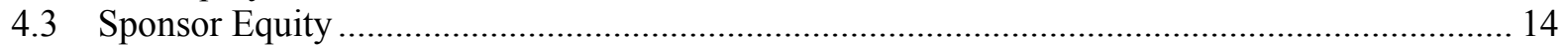

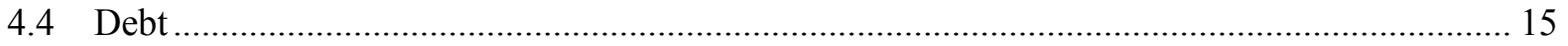

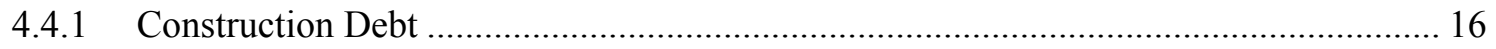

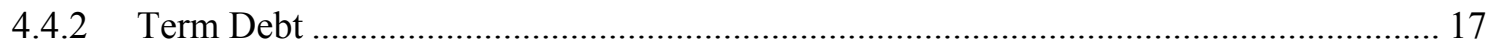

4.4.3 Back-Leverage ........................................................................................ 18

4.4.4 Other Forms of Debt ............................................................................... 19

4.5 Financial Capital Stack........................................................................................... 20

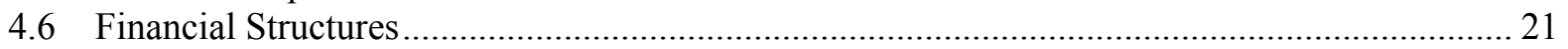

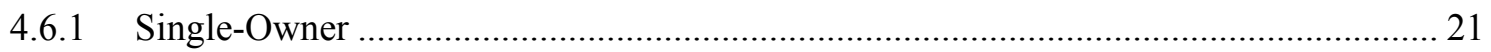

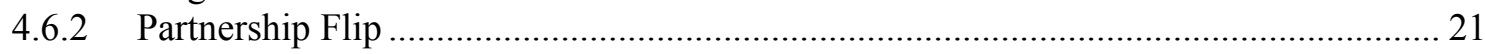

5 Corporate Purchasing and Procurement .......................................................................... 24

5.1 Corporate Onsite Procurement ............................................................................... 25

5.2 Corporate Offsite Procurement ............................................................................ 26

5.2.1 Direct PPAs through Virtual Net Metering .......................................................... 27

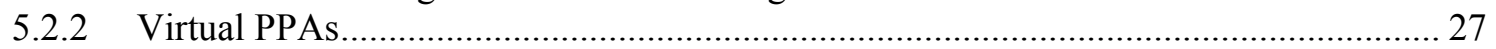

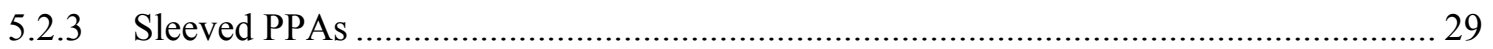

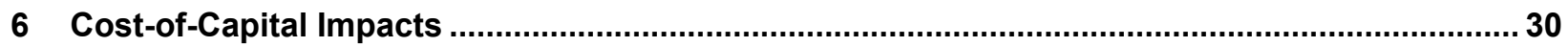

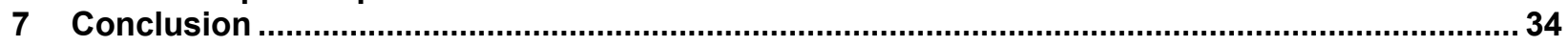

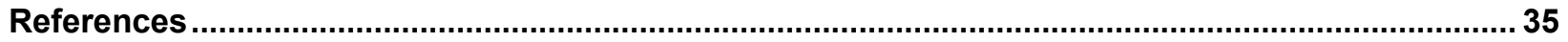




\section{List of Figures}

Figure 1. New U.S. investment in wind energy 2006-2016 ................................................................ 1

Figure 2. Timing of the federal tax benefits generated by a wind project ............................................. 13

Figure 3. Comparison of the relative risks and returns for typical wind energy financing sources............ 21

Figure 4. Hypothetical partnership flip structure for a $\$ 100$ million wind project ................................... 23

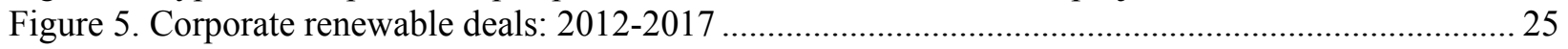

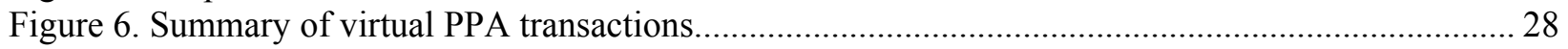

Figure 7. Comparison of financing scenarios to energy prices .............................................................. 32

\section{List of Tables}

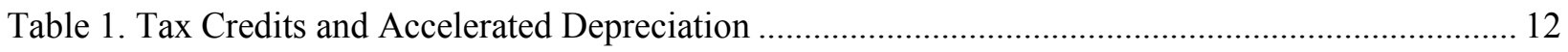

Table 2. LCOE Comparison of a Higher Cost and Lower Cost Financing Scenario................................ 31 


\section{Introduction}

By the end of 2016, cumulative U.S. wind generation capacity stood at 82.2 gigawatts (GW), expanding by $8.7 \mathrm{GW}$ from 2015 installations levels (AWEA 2017; Ray 2017). Wind energy added the most utility-scale electricity generation capacity to the U.S. grid in 2015 and the second most in 2016 (Lee and Darling 2016; Ray 2017). Project investment in wind in the United States has averaged $\$ 13.6$ billion annually since 2006 with a cumulative investment total of $\$ 149$ billion over this time period (BNEF 2017). ${ }^{1}$

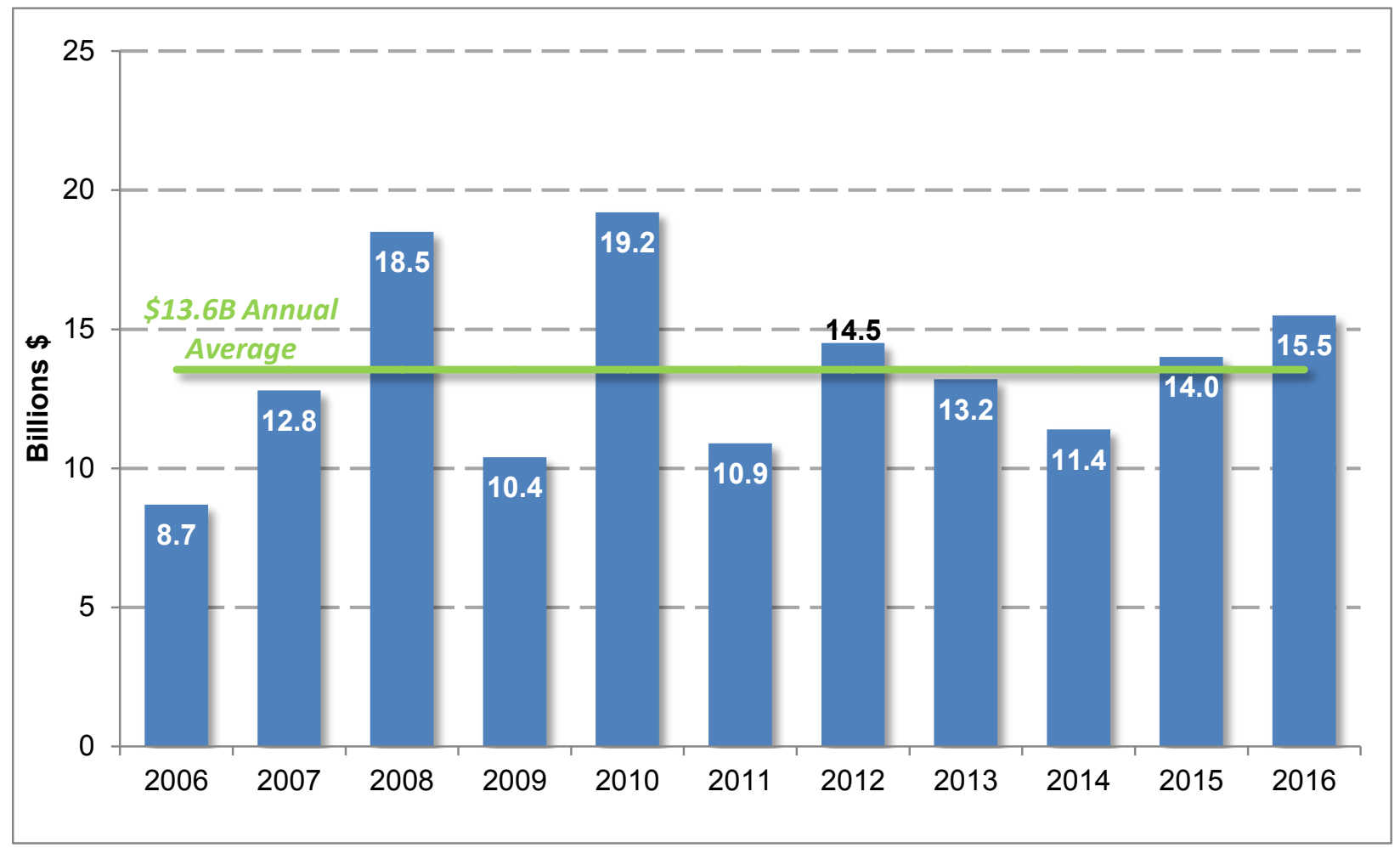

Figure 1. New U.S. investment in wind energy 2006-2016

Source: BNEF 2017

Despite its consistent investment levels over the last decade, some investors still consider wind energy as a specialized asset class. The level and depth of understanding and comfort with the technology, market, policies, and financing practices that underpin the deployment of wind energy naturally varies among financiers. Limited familiarity of the particular asset class can both limit the pool of potential investors and drive up costs for investors. And for a capitalintensive project such as a wind farm, where a 100-megawatt (MW) project can cost, on average, nearly \$165 million (Wiser and Bolinger 2016), reducing the cost of capital even by just a half percentage point could result in measurable cost savings and improved competitiveness and ultimately enable greater penetration on the grid.

\footnotetext{
${ }^{1}$ As reported by BNEF (2017), all figures are in nominal dollars. BNEF 2017 investment estimates include public capital sources such as stock and bond markets, commercial capital from banks and insurance funds, research and development funds from corporations and governments, and other sources such as private equity or venture capital.
} 
To this end, the National Renewable Energy Laboratory (NREL) is leading an effort called "Performance, Risk, Uncertainty, and Finance" or "PRUF" under the Atmosphere to Electrons (A2e) initiative sponsored by the U.S. Department of Energy (DOE). A2e is focused on risk mitigation, and PRUF in particular is focused on the mitigation of risk related to investment and financing of wind energy projects. Through activities such as PRUF and general industry maturation, a broad and widely understood assessment of wind energy project risk among developers, investors, and policymakers can help to expand the potential pool of industry investors and drive down the cost of capital for the wind industry. Reducing the cost of capital can lead to attendant - though modest-reductions in the levelized cost of energy (LCOE), which in turn contribute toward wind energy competitiveness in the marketplace (EERE 2017).

This publication provides an overview into the wind project development process, capital sources and financing structures commonly used, and traditional and emerging procurement methods. It also provides a high-level demonstration of how financing rates impact a project's all-in cost of energy. The goal of the publication is to provide a representative and wide-ranging resource for the wind development and financing processes. It is organized into five sections after this introduction:

- Section 2 offers a general summary of the various risks during the development, construction, and operation phases of a wind project. Risk is a critical factor in the availability and cost at which project sponsors (owners) can access debt and equity capital as well as the rates offered.

- Section 3 takes a chronological tour through the wind project development cycle, from screening and pre-development all the way through commissioning and project operation. It also indicates what kind of capital is typically invested at each stage.

- Section 4 discusses three capital sources in greater depth: sponsor equity, tax equity, and debt. The subsection on tax equity also includes a brief overview of the federal tax benefits available to wind projects as of this writing. The section concludes with a discussion of the financial structuring designed to monetize these tax benefits.

- Section 5 covers the various contractual instruments by which wind projects can earn revenue from the energy they generate with a focus on corporate purchasing.

- Section 6 presents a high-level analysis to demonstrate the effect of variation in the cost of capital (through improved investor risk perception, robust due diligence, and other practices) on LCOE, which contributes to an energy project's competitiveness and feasibility in a particular market. 


\section{Risk and Uncertainty in Wind Projects}

Commercial-scale wind projects are large, complex, and capital-intensive infrastructure assets. Like any other large-scale energy or infrastructure project, decisions to invest in wind projects are built on expectations about the future that are subject to some amount of uncertainty, including electricity price projections, changing market demand, technology and cost evolutions over time, and yearly weather patterns among other factors. The owners of these wind projects (referred to hereafter as "project sponsors") extensively study these uncertainties to develop a model that forecasts the project's financial performance and the returns it can pay to its investors.

In simple terms, risk is a measure of the uncertainty of future outcomes and their impact on a project. Risk is ubiquitous across financial investments, and investors can be made comfortable with accepting certain types of risk knowing that reduction mechanisms and remedies can be put into place. Higher risk generally offers the potential for a correspondingly higher return on investment. Any event that could have a negative impact on the investment is typically referred to as a "risk event" and largely consists of the scenario, the probability of occurrence, and the magnitude of impact.

One tool used to examine the effects of risks and uncertainty in a wind project's performance is through analysis with a pro forma financial model. ${ }^{2}$ Each of the parameters underlying the pro forma financial model carries a degree of uncertainty that introduces an element of risk to the project. Project sponsors strive to identify sources of risk, quantify the potential impact of each risk, and develop strategies to minimize the potential of these risks to negatively impact project outcomes. As with all investments, some risk inevitably remains in wind energy despite best efforts to analyze and control for uncertainties.

Investors, industry analysts, and financial ratings agencies describe a few major areas of risk with land-based wind energy projects (Fitch 2016). ${ }^{3}$ These perceived risks are summarized at high level below.

- Project Development Risk. This risk reflects the uncertainty of a project reaching commercial operations and the point at which it generates electricity and therefore revenue. A project developer will likely pursue the development of multiple potential projects at a time and could choose to pause or permanently halt the development activities of any one project for any number of reasons. Site control difficulties, lack of transmission access, wind resource uncertainty, and unfavorable market dynamics are among the more commonly reported issues. In general, the time and cost spent developing a wind project is considered entirely at risk because an unsuccessfully developed project has only a minimal asset value, and limited or no revenue potential. ${ }^{4}$

\footnotetext{
${ }^{2}$ The term pro forma is Latin for "for the sake of form" (Investopedia 2016). A pro forma financial estimate is defined as "assumed, forecasted, or informal information presented in advance of the actual or formal information" (Business Dictionary 2017).

${ }^{3}$ For a more comprehensive listing, the investment rating agency Fitch provides a thorough analysis in "Rating Criteria of Onshore Wind Farms Debt Instruments" (Fitch 2016). The Fitch report summarizes risk for only one type of investors - a lender - though it is broadly applicable to other types of investors (e.g., tax equity) as well.

${ }^{4}$ The possible exception here is where a project development company may transfer a partially-developed project to another developer.
} 
- Construction Risk. Fitch (2016) classifies the construction risk of wind projects as "low in complexity" based on the industry's extensive history constructing land-based projects. The construction of a project is generally viewed as an acceptable risk after turbine pricing has been secured, and the construction is likely completed with a fixed-price contract with built-in protections for the investors. Fitch does note, however, that delays in the supply chain can have a material impact on the ability of the project to generate revenue. Delays and over-runs can be contractually mitigated through guarantees, funds set aside for contingencies, and punitive payments.

- Regulatory Risk. This is the risk arising from the inability to predict with complete certainty if regulatory schemes supporting wind energy development will be available for the term described at the onset of the project. For example, the use of tax incentives that are recovered over a period of 10 years and green energy attributes that also may have multi-year contracts both provide a revenue source to the project, but are only valuable if they are considered secure by the investor in the project.

- Market or Selling Price Risk. This risk encompasses the extent to which the project's source of revenue is subject to an unknown selling price (e.g., if the plant is "merchant" and relies on revenues from selling into an electricity market with variable pricing rather than a fixed-price PPA contract). All else being equal, a project that has a guaranteed price for its energy over its entire lifetime has less uncertainty and therefore less perceived risk compared to a project with some market price exposure. Of course, while guaranteed power prices protect project investors from the downside of market exposure, they also prevent the investor from benefitting from the potential upside of increasing market prices above the locked-in rate. Another component of the selling price risk involves the ability of the electricity purchaser to pay for the energy as contractually obligated.

- Pre-Construction Energy Estimate Risk. This is the risk associated with the forecast accuracy of the amount of energy a wind project is expected to generate annually and over its lifetime. Expected production is a critical input to a financial model, as it will significantly factor into determining investment viability, sizing, and profitability. It is also the key focus area of PRUF's 2016 energy estimate primer (Clifton et al. 2016). Fitch's rating criteria for wind projects notes that the ratings agency will typically reduce any pre-construction energy estimate by up to $10 \%$ based on a number of project-specific factors (Fitch 2016).

- Technology and Energy Production Risk. This risk category includes several different components that all manifest as reduced energy production in a given year, and consequently diminished electricity sales volume and revenue. There are many factors that contribute to production risk that can be either temporary or permanent in nature. Some of these factors include weather anomalies, technology reliability, project availability, curtailment, and unexpected operations and maintenance (O\&M) events. Availability generally refers to the ability of the operator to keep the wind project working and producing electricity. Curtailment can refer to the situation where a project is technically capable of delivering power to the grid but fails to do so for either bulk 
electric system reliability issues or economic reasons. ${ }^{5}$ Similarly, O\&M risk typically refers to the track record of the entity responsible for running the wind plant to service turbines in a timely manner and according to budgeted forecasts.

\footnotetext{
${ }^{5}$ System reliability curtailment typically refers to a situation in which a generating asset must curtail its power to protect the safety of the grid system. Economic curtailment typically refers to a situation in which the price of electricity bid into the wholesale market is not accepted. The renewable energy asset owner typically bears the risk of system reliability and emergency curtailment; however, it is up to the contract to determine whether the project owner or electricity purchaser bears the risk of economic curtailment.
} 


\section{Wind Energy Project Lifecycle}

Wind project development contains multiple phases, each with its own unique set of tasks, risks, capital sources, and potential obstacles to overcome. Collectively these phases represent the lifecycle of a wind energy project, and while there is no standard definition or sequencing of the project development phases, most approaches envision a comprehensive set of actions that can be carried out in parallel or in some instances in a stage-gate manner.

During the development process, a central coordinating party (the developer or sponsor) ushers the project through a series of activities that addresses all the requirements for reducing risks and uncertainties, completing milestones, and advancing a project from conceptual to concrete. Development activities are directed to demonstrating and assembling the key criteria of a successful wind project, which include but are not limited to the following:

- Verified resource (feasible wind characteristics)

- Controlled location (a permitted site)

- Market for product (demand for energy and other grid services)

- Path to market (transmission access).

The remainder of this section briefly describes the major phases of project development.

\subsection{Screening}

The initial phase of a project is providing a first-order assessment of its overall feasibility within the larger energy market. Typically, a developer will first evaluate the suitability of the site through a virtual screening, followed by a more robust, dedicated wind study. For a virtual assessment, regional wind profiles allow for a quick desktop-based screening to determine estimated winds based on the local characteristics rather than the specific site.

During the initial screening, a project developer will also conduct a "fatal flaw analysis" that gauges the critical aspects across a number of different potential sites and tries to identify all mission critical barriers to development. This step is undertaken very early in the development process so as to avoid investing too much time and capital in a project that ultimately may prove unfeasible. Some common issues that developers may consider a fatal flaw include:

- Poor wind resource

- Lack of transmission access

- $\quad$ Limited site access

- No electricity purchaser

- Insufficient local support and buy-in

- Environmental sensitivities

- Historical or cultural sensitivities

- Permitting complications. 
Investment required at this initial screening phase is relatively small and typically sourced from the developer's own funds. Outside investment is not typical at this early stage due to the highrisk nature of the activity and the uncertainty of any one project becoming fully developed and commercially operational (Springer 2013). ${ }^{6}$ Sources of funding at this stage for a small developer may be personal funds from the principals in the development company, landowner(s), friends and family, or other willing early-stage investors. Larger developers will usually fund scouting and initial prospecting using capital available on their own balance sheet. They may also purchase promising projects from smaller developers who have conducted initial screens.

\subsection{Pre-Development}

If the initial screening of a site indicates a promising resource and has no apparent fatal flaws, then the developer may elect to continue with early stage development activities. At this stage, a more credible assessment of the wind resource will be conducted, requiring an onsite, structured wind-measurement program be implemented. In many cases, multiple meteorological towers will be deployed temporarily across the site to further assess the wind speed, direction, duration, and turbulence. A 12-month (or more) data collection period with a high level of data quality assurance will provide input to a power production model that will be used later for construction financing (Vestas, n.d.). Robustness of the wind data varies across developers and projects, although, generally, the more detailed and specific the data, the higher the likelihood that the developer will secure funding for construction. The quality of the meteorological monitoring program will contribute to both the availability and the cost of capital.

Another crucial aspect of the development activity is to ensure sufficient access to and certain control over the project site (Taylor and Parsons 2008). Even the best wind data is of little value without also having sufficient control over the potential site. Though the developer will typically treat the wind data as highly confidential, the developer will also need to forge relationships early with potential wind turbine hosts on the site. ${ }^{7}$ Site control can be contracted through various mechanisms including a land lease or outright purchase. The developer will typically seek site control for an extended period to accommodate the timeline of the development and operations processes.

During the initial development phase, the developer may also have preliminary discussions with county commissioners, local government agencies, community leaders, and other key stakeholders to begin to secure the permits necessary for construction of the project. Presenting the local authority having jurisdiction with the meteorological monitoring program findings may give the commissioners an opportunity to identify whether they will likely object to all or a portion of an eventual wind farm located at the site.

At the early development stage, the developer will also prepare an economic assessment for converting the wind resource into marketable electricity at the chosen site. A simplified pro forma financial model using typical assumptions for technology, reliability, availability, degradation, transmission losses, revenue, expenses, incentives, and other inputs will indicate

\footnotetext{
${ }^{6}$ Risk at various levels from prospecting through development is not easily quantified without understanding success rates for the pool of wind energy developers, and developers are often hesitant to publicize such detail (Taylor and Parsons 2008). Therefore, characterization of development risk herein is illustrative.

7 The "site" could entail multiple landowners and multiple counties.
} 
whether a wind project at the site will deliver a satisfactory return on investment. Such a model can also help forecast whether the project will produce power at an economically attractive price. A business case is likely developed with updates as more details come to light and conditions and assumptions change, demonstrating whether or not the project appears to be economically feasible (Springer 2013).

\subsection{Development}

As a conceptual project begins to show more promise and risks are mitigated, development activity in the project will typically accelerate. Preliminary design and site engineering work can begin with a basic layout of the project on the site. At this stage, a utility PPA or comparable instrument will be pursued. The turbine vendor will be selected and a turbine supply agreement will be considered. The impact on the local electrical grid will also be studied through system impact and interconnection studies to help determine if any upgrades may be necessary for the wind farm to connect to the grid and the market served (Burns \& McDonnell 2009). A construction contractor or multiple contractors may also be preliminarily screened and qualified.

At this stage the likelihood of the project reaching completion will have increased as will the level of investment in the project. Larger developers will usually continue to fund such development with their own internal capital, while smaller developers may look for additional support through partnerships with external funding sources, a sale of development rights, and other approaches.

As the end of the development stage approaches and construction of the wind farm appears to be reasonably likely, the projected future revenue of the project will be heavily scrutinized to secure outside commercial financing. The various agreements in the development stage, however, are typically pliable so they can be modified if necessary. The investor will typically provide term sheets that outline the specifics of the investment to ensure that the parties agree to the basic parameters before advancing to the more costly final negotiations. Outside advisors such as independent engineers and tax consultants will also be engaged to help investors understand project risks from an objective perspective (Fitch 2016).

At the end of the development stage, construction is ready to begin, pending the finalized decision(s) for investment and the financial close (the point at which the financial documents are signed and capital begins flowing to the project from the investors).

\subsection{Construction}

A wind farm will begin construction when the developers give the Notice to Proceed to the contractor(s). At this stage, the project has secured the necessary financing and development risk has shifted to construction-oriented risks, including unforeseen construction barriers, cost and timeline overruns, and others. Because of the large number of wind projects successfully completed, construction of land-based wind farms is generally well-understood by construction contractors, insurance providers, and equipment vendors among others (Fitch 2016).

Activities during the construction phase include the procurement of materials; the physical building of the wind farm; management of construction site, personnel, and process; reporting to investors; and community relations. The elements of the physical construction process generally 
include construction of support roads; concrete pumping for the turbine pad; turbine delivery; setting the tower section; lifting the nacelle; assembling the rotor; lifting and attaching the rotor; installation of a collection system of wiring to electrically connect to a substation; and construction of an O\&M support building (We Energies, n.d.).

In a typical construction financing scenario, the project sponsor will be expected to contribute significant capital to the project, colloquially referred to as "skin in the game." This contribution ensures that priorities between the different parties during construction are aligned. The remainder of the investment is typically a loan from a commercial bank (aptly called a "construction loan"). In many cases the construction lender will also provide longer-term financing for the project. This commonly happens through a conversion, where the construction loan is refinanced by the same lender as a term loan, with a different interest rate, maturity, and term sheet.

During the construction phase but before the wind farm is fully completed, the project sponsor may be able to bring certain turbines online to deliver test electricity to the grid for sale. The revenue received on such electricity sales before the commercial operation date of the wind farm may be sold at separate prices from the power delivered after the project is fully operational and may be contributed as sponsor equity.

\subsection{Operations}

Operation of the wind farm generally commences once a substantial amount of construction has been completed. "Substantial completion" generally means that each wind turbine has been commissioned and certified, electricity will be delivered to the grid, and there is coordination with the grid operator and utility or power purchaser. ${ }^{8}$

During the first year of the wind farm operation, the operator (the developer/sponsor or a contracted third-party operations manager) will typically ensure that any challenges-from hardware (e.g., blades, gearboxes, etc.) to software (e.g., turbine electronics, wind farm controls) - are tracked and remedied. This is sometimes referred to as "teething." These actions can reduce the availability of the wind project and diminish the amount of energy produced by the system operating in its initial phase compared to pre-construction estimates (Fitch 2016). By the second year of operation, the wind farm is generally expected to be producing and selling electricity at a level consistent with the forecast presented in the wind plant's pro forma financial model. The level at which operational wind projects have been producing energy compared to their earlier performance forecasts, however, varies (Fitch 2014; NAW 2014; Bailey 2016).

The plant operator may be contracted to carry out both routine O\&M activities as well as major maintenance measures, although the original turbine supplier may also be involved for some technically complex activities. Major maintenance is generally pre-funded through reserve accounts, which are set up during the project's financial close. As the major maintenance reserve is drawn upon to repair failures, it is usually replenished from the project's cash flow. After a few years of successful operation consistent with the original business plan, risk is generally considered to be at its lowest in the project's operating lifecycle.

\footnotetext{
${ }^{8}$ See IRS 2013 for guidance on placed in service conditions (IRS 2013).
} 


\subsection{End of Life}

As the wind farm approaches the end of its original estimated useful life, the equipment may be decommissioned, overhauled, or repowered. These activities will depend on land lease

provisions, PPAs, and the economics of different decision pathways. Typically, wind energy contracts will provide a financial mechanism such as posting a performance bond or requiring a reserve account be set aside to fund the cost of the end of life activities to restore the site to a pre-agreed-upon condition. 


\section{Capital Sources}

Generally, wind project financing is composed of three main sources of capital: equityincluding sponsor equity and tax equity, and debt. The blend and proportion of each of these capital sources in a given project is referred to as the capital structure or capital stack. At a basic level, most wind project capital structures will include a sponsor equity partner (commonly a developer), a debt provider, and many projects will use a third party tax equity partner that provides upfront capital in exchange for the tax benefits of the project.

Subsections 4.1-4.3 provide focused discussions on each of the primary capital sources, while Section 4.4 summarizes how these sources combine to form capital structures.

\subsection{Equity Capital}

Equity generally refers to an ownership share of an asset, which can take the form of a security (e.g., stock or share) or a direct investment in a company. Equity investors typically stand to lose some or all of their investment depending on whether the company or project is successful. Conversely, equity capital also stands to gain beyond original expectations if the company or project outperforms forecasts or if the project is sold to another party.

There are multiple ways in which an equity partner can invest in the construction and/or longterm ownership of a wind project. This report looks at the two most common forms: tax equity and sponsor equity. Before jumping into these equity options, a basic overview of the federal tax incentives available to wind technologies is warranted.

\subsubsection{U.S. Federal Tax Incentives}

The United States Federal Government incentivizes renewable energy projects principally through the tax code. As of this writing, wind technologies are eligible to receive either the production tax credit (PTC) or the investment tax credit (ITC) (one or the other, but not both) as well as accelerated depreciation tax offsets through the Modified Accelerated Cost Recovery System (MACRS). The tax credit incentives (the PTC and ITC) provide an after-tax credit on tax liabilities (i.e., the taxes paid) and thus are often described as dollar-for-dollar tax incentives. Accelerated depreciation, by contrast, provides a reduction in taxable income against which the tax rate is subsequently applied, and so is described as a before-tax incentive. As of this writing the PTC is currently worth $\$ 0.024$ for every $\mathrm{kWh}$ generated over a 10 -year period ${ }^{9}$ while the ITC is structured as a one-time credit valued at $30 \%$ of eligible system costs (Novogradac 2016). For projects to claim the aforementioned full PTC or ITC values, however, the project is required to have begun construction prior to December 31, 2016. ${ }^{10}$ Projects that begin construction in 2017 through 2019 are available for a reduced-value PTC or ITC, shown in Table 1.

Depending on the performance of the project, the net present value of the full $\$ 0.024$ value of the PTC combined with the accelerated depreciation benefits have historically provided in excess of $50 \%$ of the project's initial capital costs in tax savings (Bolinger 2014). ${ }^{11}$ The rules governing

\footnotetext{
${ }^{9}$ Periodically adjusted for inflation.

${ }^{10}$ Qualifying criteria for begun construction clarified in IRS 2016 and IRS 2017a.

${ }^{11}$ A diminished value of the PTC or ITC would reduce this estimate somewhat. Note that only the PTC or ITC is reduced in value while, as of this writing, the MACRS schedule is a permanent part of the tax code.
} 
the eligibility, receipt, and other aspects of the tax credits are codified in the Internal Revenue Code, specifically Section 45 for the PTC and Section 48 for the ITC. The rules related to the accelerated depreciation of property for tax purposes are found in several places, including Section 168, Section 48, and Internal Revenue Service (IRS) Publication 946 (IRS 2017b). ${ }^{12}$ In addition to the five-year MACRS schedule, qualifying renewable energy projects have the option to depreciate $50 \%$ of an investment operation under a so-called "bonus" depreciation scheme. ${ }^{13}$ See Figure 2 for an illustrative example of how PTC and 5-year MACRS are received over the life of a typical wind project (Bolinger 2014).

Table 1. Tax Credits and Accelerated Depreciation

\begin{tabular}{|c|c|c|c|c|}
\hline & & PTC & ITC & \\
\hline & Year & Value & Value & Accelerated Depreciation \\
\hline \multirow{4}{*}{ Value/Basis } & 2016 & $\begin{array}{l}100 \% \text { PTC } \\
(2.4 \phi / k W h)\end{array}$ & $30 \%$ & \multirow{4}{*}{$\begin{array}{l}\text { Depreciation of qualifying } \\
\text { project costs according to } \\
\text { specified annual schedule. For } \\
\text { wind, } 100 \% \text { of qualifying costs } \\
\text { (and } \sim 92 \%-98 \% \text { of total project } \\
\text { costs) can be depreciated in the } \\
\text { first six years of commercial } \\
\text { operation. The principal section } \\
\text { of the U.S. Internal Revenue } \\
\text { Code that deals with } \\
\text { depreciation is Section } 168 \text {. }\end{array}$} \\
\hline & 2017 & $\begin{array}{l}80 \% \text { PTC } \\
(1.8 \phi / k W h)\end{array}$ & $24 \%$ & \\
\hline & 2018 & $\begin{array}{l}60 \% \text { PTC } \\
(1.4 \phi / k W h)\end{array}$ & $18 \%$ & \\
\hline & 2019 & $\begin{array}{l}40 \% \text { PTC } \\
(0.9 \phi / k W h)\end{array}$ & $12 \%$ & \\
\hline $\begin{array}{l}\text { Expiration/Step- } \\
\text { Down }\end{array}$ & \multicolumn{3}{|c|}{$\begin{array}{l}\text { Wind projects must be deemed to } \\
\text { have begun construction by each year } \\
\text { to qualify for credit value. Credit value } \\
\text { steps down from } 2017-2019 \text { and } \\
\text { expires completely on December } 31 \text {, } \\
\text { 2019. Qualifying criteria for "begun" } \\
\text { construction clarified in IRS } 2016 \text { and } \\
\text { IRS 2017a. }\end{array}$} & $\begin{array}{l}\text { 5-year MACRS: No expiration } \\
\text { Bonus Depreciation: } 50 \% \\
\text { depreciation allowed in year } 1 \text { of } \\
\text { project operation until } \\
\text { December 31, 2017; 40\% until } \\
\text { December 31, 2018; and 30\% } \\
\text { until December 31, } 2019 \text {. }\end{array}$ \\
\hline
\end{tabular}

Source: Updated from Lowder et al. 2015 and Novogradac 2016

\footnotetext{
${ }^{12}$ Section 168 defines accelerated depreciation broadly, and Section 48 contains the provision for an investment tax credit for several renewable energy technologies. Publication 946 contains MACRS schedules, including the 5-year MACRS for eligible renewable energy technologies (IRS 2017b). Note that election of the ITC also requires a reduction in the eligible cost basis for MACRS equal to one-half the value of the tax credit (e.g. $15 \%$ for the $30 \%$ ITC and so forth).

${ }^{13}$ Bonus depreciation can generate sizable tax losses in the first year of the project and thus requires an entity with a significant tax liability to make efficient use of it. Moreover, high tax losses will decrease the tax equity partner's capital account, which can introduce complications and risks into the financial structure of the project. For this reason, tax equity investors may forgo the use of bonus depreciation in wind deals (Burton 2016).
} 


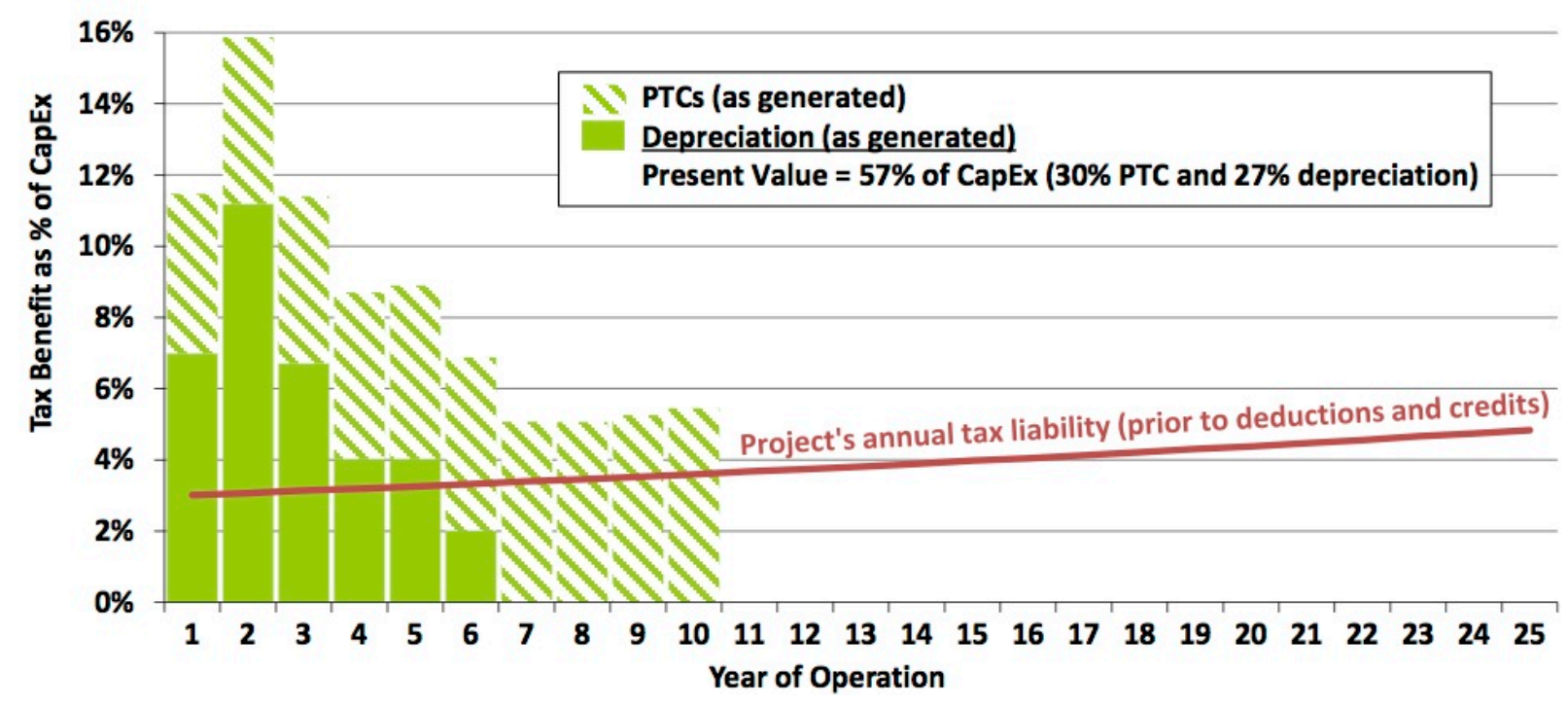

Figure 2. Timing of the federal tax benefits generated by a wind project ${ }^{14}$

Source: Bolinger 2014

\subsection{Tax Equity}

To make the most efficient use of the tax benefits - the PTC or ITC coupled with MACRS - a taxable entity must apply them to taxable income (depreciation) and tax liability (credits) in the year in which the benefits were generated. However, many sponsors or developers in the wind industry do not have enough tax capacity to do so and would otherwise have to carry the benefits forward (thus depleting their present value due to the time value of money) if it were not for the ability of outside investors to "monetize" them. These investors, known as tax equity investors, will commit capital to a project in exchange for access to the PTC or ITC and accelerated depreciation, thus providing the project with a sizable portion of its capital needs (typically $30 \%-50 \%$ of the total). Because this type of investment requires significant capital and tax liabilities, tax equity investors are often large financial entities such as banks and insurance funds. Several multinational corporations are also active in the tax equity market.

To access the tax benefits, investors must demonstrate ownership of the project assets for tax purposes (a determination made by the IRS). In wind projects, this ownership usually comes in the form of a partnership with the developer (unless the project is owned by a single entity that can wholly use the tax incentives themselves). The partnership is structured as a special purpose vehicle (SPV) - either a limited liability partnership (LLP) or limited liability company (LLC) into which each of the partners (developer and tax equity) makes a capital contribution. Each partner is allocated a certain share of the project value streams - namely income (cash) and tax benefits (deductions and credits) - which change over the life of the partnership. ${ }^{15}$

\footnotetext{
${ }^{14}$ CapEx refers to the capital expenditures of a wind project.

${ }^{15}$ Renewable energy projects that utilize the investment tax credit (Section 48) can execute one of three tax equity financial structures: partnership flip, sale leaseback, and inverted lease/lease pass-through. However, projects that utilize the PTC are not permitted to execute lease structures as per the "owner/operator" requirement in Section 45. For this reason, the partnership flip is the dominant financial structure to monetize tax equity for wind projects.
} 
Two criticisms of utilizing outside tax equity investments are frequently reported. First, there are relatively few active tax equity partners in the market in any given year. ${ }^{16}$ Because the demand for this type of capital often outpaces the available supply, the tax equity investors may require a higher return than a comparable debt product, ranging generally from $7 \%-10 \%$ based on the particulars of the investment and the overall supply of market tax equity (Shurey 2016; Shanahan, Wisniewski, and Andiorio 2017).

The second criticism to tax equity financing is also a function of the complicated structuring. Setting up a deal entails high transaction costs - e.g., fees associated with legal services, tax opinions, consultants, financial structuring, and other services (Feldman, Lowder, and Schwabe 2016). Such transactional costs reduce the nominal value of the tax incentives and can also drive deal flow to larger project sizes (which keep the more-or-less fixed transaction costs low relative to deal size). This can have the effect of limiting the competitiveness in the wind development market place, as smaller developers may not be able to access financing as readily as larger players.

\subsection{Sponsor Equity}

The sponsor equity ("sponsor") in a project most closely resembles a traditional equity investor and often can be the original developer of the project. The sponsor equity is typically the ultimate financial backstop in the project, and also the last entity to receive payment in the distribution of income in the project. Because the sponsor commonly faces the highest risk in the partnership, it will often also have the highest return requirements. However, because the sponsor equity is typically either back-levered (discussed later) or is only a marginal portion of the capital stack, this highest cost equity may exert only a limited impact on the project's weighted average cost of capital (WACC) - the combined cost of capital from all the sources in the project's capital stack).

If the sponsor is also the developer, it is responsible for bringing the project from initial concept through the extensive development phase all the way to construction and commercial operations. ${ }^{17}$ In many cases, the sponsor may ultimately manage the long-run functioning of the project, providing O\&M services, fulfilling the obligations of the PPA (if there is one), or managing the dispatch of electricity into wholesale markets. In some cases, the sponsor can also be a relatively passive or non-active owner in the project and contract out the day-to-day O\&M of the project. The sponsor may also receive some of the project's income distributions as well as a "development fee" that it collects upon commercial operation of the project (Bolinger 2014). This fee varies, but some report ranges from $8 \%-15 \%$ of the project capital costs, which can be paid from a portion of the tax equity's initial investment in the partnership, from any leftover construction debt, or from a portion of the term debt disbursal (Martin 2011; Feldman, Lowder, and Schwabe 2016). Sponsor equity largely receives its returns on a primarily cash basis rather than through distribution of the tax benefits.

\footnotetext{
${ }^{16}$ One of the reasons that the pool of tax equity investors is limited (which in turn can drive tax equity yields higher for the limited supply relative to demand) is the passive activity loss and at-risk rules in the U.S. Internal Revenue Code. Both rules effectively prevent certain entities from accessing the full value of the tax benefits available to investors in renewable energy projects (Eliason 2012).

${ }^{17}$ In some cases, more than one developer can be involved in the process of conceptualization, project development, construction, and ultimate ownership of the project. This will happen when one developer sells a project to another at the outset of any one of these phases.
} 
The sponsor can raise funds for project development and investment via several sources, including their own balance sheet; funding from customers and suppliers; outside private investors; and others. More recently, companies have looked to the public capital markets, employing vehicles such as yieldcos once projects were fully developed (see textbox below) to raise equity funds at a lower cost than other sources. Additionally, a more mature company may "go public" and issue stock in the public markets and the proceeds can be used to fund development work.

\section{Financing in the Capital Markets: Yieldcos}

Capital markets are the transactional marketplace into which businesses, governments, individuals, and other entities sell debt and equity instruments to investors, and investors sell such instruments to one another. The most common instruments sold in the capital markets are bonds (debt) and stocks (equity) (Goldman Sachs 2014). In the last several years, renewable energy developers have turned their attention to the capital markets as a source of low-cost finance that could help to reduce project LCOE. Two means by which developers have accomplished this are through yieldcos and asset-backed securities (see textbox below for a discussion of securitization and asset-backed securities).

A yieldco is a corporate entity (a limited liability corporation, limited liability partnership, or joint venture) that aggregates a portfolio of energy assets for which ownership sharesi.e., stocks - are sold. Yieldcos are commonly subsidiaries of larger parent developers that hold and generate additional value from operating assets. As such, yieldcos often get a right-of-first-offer for projects developed by their parent companies, and this in turn can give the parent a captive means to sell completed projects and redeploy capital. Yieldcos also purchase operating projects and pipelines from other developers to grow their assetbase (Lowder et al. 2015).

Yieldcos allow project developers to potentially access lower-cost equity capital, and to source capital for growth that might otherwise be difficult to come by (either through corporate bonds, stock issuance, or other means). The principal benefit of a yieldco for investors include: limited taxation (accelerated depreciation benefits can allow yieldcos to eliminate corporate-level tax for a number of years); long-term predictable cash flows; and, until recently, the promise of dividend growth. This last benefit became difficult to achieve as yieldco sponsors found the practice of continually expanding their asset bases to be difficult to sustain. This and other factors have led to a dormancy in yieldco markets that has largely persisted since late 2015. Some of the more stable yieldcos have been able to raise some equity since that time, though others have not (owing, in some cases to financial difficulties at the corporate parent) (Lowder et al. 2015).

\subsection{Debt}

Debt is a contractually-arranged loan that must be repaid by the borrower and in which the lender has no ownership shares in the company or venture. Debt is generally considered a lower-risk investment and therefore a lower-cost funding source relative to equity, though in the case of tax 
equity financing risk may be considered comparable between the two (Shurey 2016; Shanahan, Wisniewski, and Andiorio 2017). Outside of this unique case, the reduced risk profile of a debt investment derives from several structural features, including but not limited to the following:

- Lenders are typically less exposed to the downside of project performance (i.e., if a project does not generate as much electricity in a year as was forecasted), but correspondingly do not enjoy the upside if the project outperforms forecasts. Moreover, once the loan is paid off, there are no remaining financial obligations from the borrower to the debt providers.

- Debt can be-though not always with tax equity involved - a "senior" investment, meaning that debt investors are typically repaid before other investors in the capital stack (i.e., most notably sponsor equity). This means that shortfalls in project revenues from underperformance, equipment failures, force majeure events, or others could cut payments to the equity holders to allow for the full and timely repayment of the loan. In some cases, however, tax equity providers may actually have repayment seniority over debt due to the relative scarcity of tax equity compared to debt (Chadbourne \& Parke 2017; Feldman, Lowder, and Schwabe 2016).

- Lenders often have financial protections such as collateral to their investment (e.g., the project assets or partnership interests) or rights to "step-in" and take over control of the company if necessary. These are often expressed in the debt "covenants"-agreements between the lender and the borrower executed before the disbursement of the loan.

The three main forms of debt in the wind market are short-duration construction debt, longerduration term debt, and back-leverage. Each of these financing products is described in more detail below.

\subsubsection{Construction Debt}

As the name implies, construction debt is used primarily to fund the engineering, design, equipment procurement, and construction of the wind project. Construction debt is typically characterized by lower-cost, shorter-tenor debt compared to the long-term debt that funds the operation of the project. Construction debt reflects the inherent risk of the project's construction processes and the associated likelihood of experiencing events that can negatively impact the ability of the project to recover its costs (Groobey et al. 2010). Examples of these risks include the project exceeding its budgeted cost or missing construction milestones, which delays the ability of the project to generate revenue. Moreover, the lender is providing construction capital against a project that is not yet generating revenue, thus the pricing is also influenced by the longer-term characteristic and credit quality of the project and its sponsor. The tenor of the construction debt (i.e., length) of the construction loan may match the construction period until the project is considered to be commercially operational.

A distinguishing feature of construction debt is the ability to access the debt financing as it is needed rather than entirely upfront (referred to as a construction drawdown schedule). For the lender this pre-negotiated scheduled helps to mitigate their lending risk by limiting the amount of capital going to the project until specific milestones have been met and excess funds are not used improperly for other purposes. For borrowers, the construction drawdown schedule allows them 
to reduce the amount of time for which that debt is outstanding and typically reduces the amount of overall interest costs paid.

The availability and pricing of construction debt will also vary depending on the type of construction strategy employed. For example, projects that employ a single designated party to engineer, procure, and construct the wind facility tend to be viewed as less risky than a multiparty strategy that may separate and allocate these tasks to more than one entity.

\subsubsection{Term Debt}

Term debt is the loan (or portfolio of loans) that refinances the construction loan at a longer maturity (construction loans typically last only a couple years while term debt loans extend to 7+ years). The interest rate on a term debt reflects the longer tenor of the term loan compared to the construction loan, as well as the risk profile of an operating asset. In some cases, capital from the term loan can be used to "take out" or, more simply, replace a portion of the sponsor equity's stake in a project, which will reduce project WACC and therefore LCOE. Accordingly, term loans are sometimes referred to as "takeout financing." Term debt can come from several sources, including commercial banks, syndicates (a group of banks operating in agreement with one another), private equity funds, insurance and pension funds, equipment manufacturers (vendor financing), and governments (in the form of concessional loans, export credit financing, and other mechanisms). Term debt can sit at either the project level or at the sponsor level, though recent trends in tax-based wind finance structures most commonly utilize debt at the sponsor level, which is described in the section on "Back-Leverage" (Chadbourne \& Parke 2017).

In the current market, much of the term debt extended to wind projects is structured as "miniperms." Mini-perms are long-term debt products (where the principal and interest are amortized over a period near the length of the contracted revenue period such as a 20-year PPA), but have shorter-dated maturities (typically 5-7 years). Due to this structuring, mini-perms will have a large balloon payment that is due when the maturity is up. This balloon payment is typically refinanced by another mini-perm loan with another principal and interest amortization schedule that extends beyond the loan's maturity (Feldman, Lowder, and Schwabe 2016).

For example, a lender might offer an 18-year loan to a wind project with a slightly longer 20year PPA (to avoid the final contracted years of the asset), but will require that, in year 7 of project operation, all available revenue coming into the project be "swept" up to repay the entire amount of the debt service. In order to prevent this, the project sponsor will refinance the original mini-perm for another 7 years, although the principal and interest payments will continue to amortize as if the loan term were longer than 7 years. 


\section{Debt Service Coverage Ratio (DSCR)}

When deciding the appropriate amount to lend to a renewable energy project, term lenders will often look at the expected production of the project in the form of exceedance probabilities. The lender will evaluate a set of probability scenarios where energy production would exceed forecasts in any given year (Fitch 2016). Typically, they will look at a 50\%, 90\%, and 99\% exceedance probability scenario (denoted as P50, P90, and $\mathrm{P} 99$, respectively).

Exceedance probabilities will also determine the debt service coverage ratio (DSCR), which is the measure of a project's cash flow to its debt obligations. A DSCR of 1.25 means that the project is anticipated to generate $25 \%$ more cash flow available for debt service (revenue less operating expenses) in a period than is required for debt service. Lenders will often require certain DSCRs at certain exceedance probabilities to afford themselves sufficient cushion in case energy production and therefore the cash flow falls below a specified amount in a certain timeframe or expenses are higher than anticipated.

\subsubsection{Back-Leverage}

When it sits at the project level, term debt can obstruct cash flows to the equity partners, impose complications in daily operations through the various covenants, and present a risk to the tax equity investor's ability to receive its anticipated economic returns. For these reasons and others, tax equity may be unwilling to lend to a project with project-level debt or may demand a higher return on its investment than it would for a project without debt at the project level. Accordingly, sponsors in the project have adopted the practice of "back leveraging" their loans. In a backleveraged debt arrangement, the tax equity and the sponsor equity form a partnership company that owns the project through different class ownership shares. The sponsor equity will typically own more junior Class B shares, while tax equity will own more senior Class A shares. The sponsor equity will pledge its ownership interests in the project company as collateral, and a lender will issue debt to the sponsor directly instead of to the project company. This removes the debt from the project company level and the loan is repaid by the cash flows allocated to Class B shares as defined in the partnership company agreement. In this scenario, the cost of backleveraged debt is based on the overall credit of the sponsor rather than the wind project itself. If there is a default, the financiers (lender or tax equity) may exercise the right to step in and take on the managing interests that were previously afforded to the sponsor.

At current interest rates and terms, back-leveraged debt is typically priced slightly higher than project-level debt, as it can represent a riskier loan than term debt from the perspective of the lender, particularly because tax equity may have preferred repayment rights. Developers, however, will often back-leverage their debt on a project in order to attract the limited tax equity funding. Back-leverage lenders tend to be a more limited group than term-debt lenders, consisting largely of commercial banks (though some private equity players have reportedly issued loans in the back-leverage market). 


\section{Financing in the Capital Markets: Securitization}

Securitization is the process by which financial assets (e.g., contracts such as leases and loans that stipulate cash transfers between parties) are pooled and processed into financial vehicles (securities), which are then sold to investors. These securities represent claims to the cash flows in a particular pool of assets, and in this way, the purchase of a security by an investor is treated as a collateralized loan. One of the principal goals for executing securitization transactions is to achieve a lower cost of capital on a pool of assetsessentially, to refinance at a lower rate (Lowder and Mendelsohn 2013).

In a wind project financial structure, it is possible for a developer or sponsor to "pledge" its partnership interests in the project LLC (and thus any income it receives from project revenues) to a securitization trust. From this trust a series of instruments (likely assetbacked securities) would be issued to investors. In this way, a developer/sponsor could swap out their high-cost equity for a lower-cost debt from the capital markets.

To date, securitzation has been most effectively executed by distributed solar sponsors (namely the large third-party finance providers such as Tesla [formerly SolarCity] and Sunrun). It is theoretically possible that a wind project could securitize its cash flows, though because wind projects tend to be large, utility-scale assets, securitization is not as readily applicable to the wind asset class at this time. The technique works well in the distributed solar space in part because the high number of offtaker contracts (residential and some commercial PPAs and leases) that back a securitization pool provides diversity that can protect investors. Additionally, there is standardization among these contracts, which facilitates pooling these assets together into a trust and alleviates the diligence requirements (and therefore costs) for investors.

\subsubsection{Other Forms of Debt}

\subsubsection{Term Loan B}

Term loan B are debt products that are underwritten by an institutional investor or other nonbank entity (such as a hedge fund or collateralized loan obligation fund), and typically issued for projects perceived as higher risk than a standard wind deal (e.g., a "merchant" project that doesn't have a PPA). Typically, term loan B debt holders will have less interaction with the project sponsor than would a bank in a term loan situation and make fewer requirements of the borrower (Dworkin and Holland 2014). Because of the risk profile, the relative relief in debt covenants, and other factors, term loans B will usually carry a higher interest rate than a loan from a commercial bank (Chadbourne \& Parke 2015, 2017).

\subsubsection{Bonds}

Bonds are a form of debt security that can be backed by a corporate balance sheet, an entity's creditworthiness (as in the case of a municipal bond), a project's projected cash flows (as in the case of non-recourse finance), or other forms of collateral. In the case of a wind project financing, the sponsor can issue corporate bonds provided it has access to the bond capital markets, or bonds can be issued by the project's SPV (in which case it is project-level debt). The 
costs, regulations, and creditor requirements are different for bonds than they are for debt sourced through a commercial bank, though the capital is still treated as a debt on the borrower's balance sheet. The terms of the debt, specified in a document called the debenture or covenant, are spelled out to protect the interest of both parties and will differ by the type of bond and the issuer. A municipality with a high credit rating will be able to issue bonds at a lower interest rate and often with a tax exemption on the interest payments to investors. Corporate entities commonly have lower credit ratings (if they are rated at all) than municipalities and other governments, and may not be able to access debt capital for as long a term and as low an interest rate.

\subsection{Financial Capital Stack}

The various financing sources described above are the principal source of funds for most wind energy projects. Collectively these sources of funds are referred to as the "capital stack" of the wind project, which represents the total financing package needed to construct and build the wind project. In some projects, a particular type of funds such as the term loan may actually be provided by more than one capital provider. This is typically because the total cost of a wind project can exceed the preferred or even maximum investment size for any one partner, requiring multiple investors to collectively make up the capital stack. For loan products this is typically referred to as a syndicated loan product, which can take a number of different forms depending on the type of the arrangement between the group of lenders. Tax equity syndication is also available (US Bank 2016).

Figure 3 below depicts an illustrative representation of the relative risks and returns of each of the main sources of capital in wind energy projects as well as the typical point of investment for the type of investment product. As described above, the construction debt, term debt, and tax equity of the project are typically the lowest-risk and lowest-cost financing available for a number of reasons, including preferred payment position, collateral in the project, contractually agreed upon yields or returns, and step-in rights, among others. Term debt is typically priced higher than construction debt due to the longer tenor of the term loan compared to the construction loan, the drawdown feature of construction loans, and other contractual protections such as full engineering, procurement, and construction wraps with fixed-price structures. Depending on a project's specifics, term debt and tax equity may be considered comparable in risk for a number of reasons, such as they both can benefit from preferred payment position, collateral in the project, and step-in rights, among others. Tax equity, however, typically commands a higher return compared to term debt due to the relatively limited supply of tax equity (wind energy competes for tax equity investment with other energy technologies or alternative tax-oriented investments such as affordable housing) and return periods that extend to around ten years, typically a few years longer than current mini-perm term debt tenors. Among the equity options, tax equity typically assumes less risk than either the sponsor or developer equity (which may be one and the same) because of senior repayment structures and pre-defined yields.

Figure 3 also shows whether the investment capital typically comes into the project prior to or following commercial operations, which have different risk profiles. The main finance sources that come into the project before reaching commercial operations are the construction loan and 
the developer equity that fund the steps preceding even the construction phase. Note that the sponsor equity and developer equity may be one in the same.

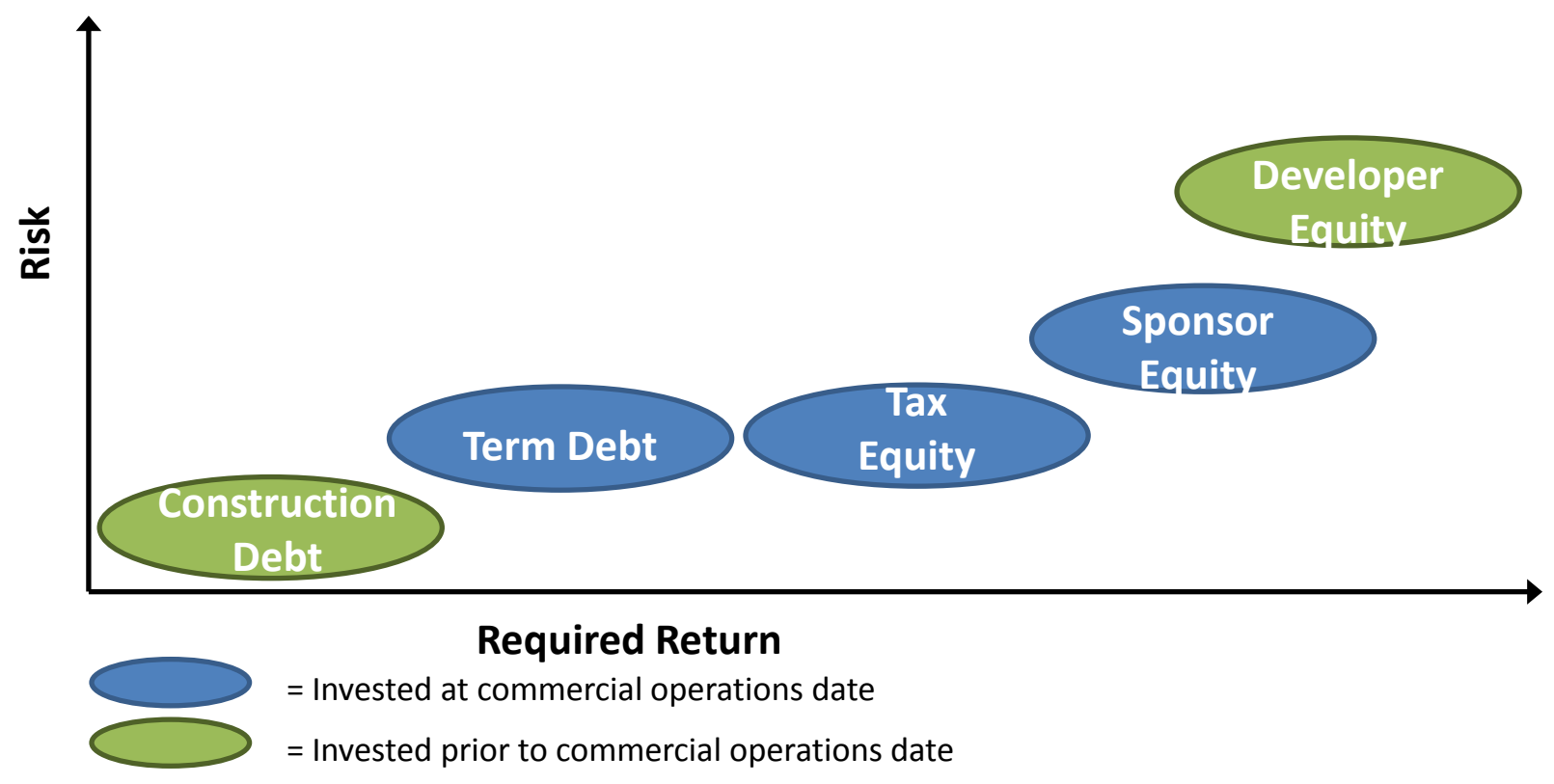

Figure 3. Comparison of the relative risks and returns for typical wind energy financing sources Adapted from Schwabe 2010

\subsection{Financial Structures}

Historically there are a number of different financial structures that have been used to fund a wind project. This section briefly touches on two of the most common structures: the singleowner model and the partnership flip. The report here largely focuses on the partnership flip, as this structure demonstrates a multiple-party finance structure with separate entities for sponsor equity, tax equity, and debt.

\subsubsection{Single-Owner}

If the sponsor of a wind project can duly fund the project with its own capital (or source sufficient debt for a portion), and also make efficient use of the federal tax benefits, then single ownership is likely the most economic option. The single ownership structure employs a single entity, to develop, finance, and operate a project themselves. With only one owner in the effort, there is no requirement for third-party tax equity and comparatively smaller transaction costs for setting up a project financial structure with an outside entity. Single ownership is also the simplest financial structure available to wind project sponsors, as it keeps control of the project, its assets, and its benefit streams wholly within their control.

\subsubsection{Partnership Flip}

The partnership flip structure is the predominant tax equity financial structure currently available to wind projects due to an owner-operator requirement in Section 45 of the Internal Revenue Code (that the owner of the wind project must also be the operator), among other reasons. Thus, the use of the Section 45 PTC prevents a lease arrangement for any project that elects the PTCs 
since the lease splits the owner and operator roles. If a wind developer were to elect the ITC instead of the PTC, additional financial structures could be used including a partnership flip, sale leaseback, or inverted lease (also known as a lease pass-through).

In a partnership flip, both equity partners (i.e., the sponsor and the tax equity) contribute the upfront capital requirement to finance the wind project and, in turn, share in the project's economic distributions. The principal economic benefits include distributable cash and tax losses and credits. Distributable cash is the revenue earned primarily from selling energy and environmental attributes less operating expenses. Tax deductions stem from accelerated depreciation, while tax credits are claimed from the ITC and PTC.

Although every project is unique, in one often-employed version for wind projects, the sponsor equity and tax equity collectively fund the entirety of the project's upfront capital requirements. The sponsor equity receives some or all of the initial distributable cash during a predefined period. Concurrently, the tax equity investor would typically receive the majority of the project's tax benefits including both the PTC as well as taxable losses generated from accelerated depreciation and some portion of the distributable cash. After a predefined period or a financial return threshold is met, the project allocations will "flip" and the distributions of distributable cash and tax benefits shift to a second sharing allocation. The secondary allocations will typically remain until the tax equity investor achieves their pre-determined internal rate of return (IRR), which is typically modeled to occur around the expiration of the principal tax benefits (i.e., around year 10 for the PTC). After the tax equity investors achieve their IRR, the project might "flip" for a second time, after which a majority of the project's remaining benefits flow to the sponsor. Figure 4 displays a schematic of a hypothetical partnership flip structure described above.

In executing a partnership flip, the sponsor and the tax equity will jointly invest in a SPV (the "partnership"), which will be the project operations entity (i.e., it will hold and manage the assets), which is also shown in Figure 4. Typically, the tax equity partner will contribute up to $50 \%-60 \%$ of the project's cost as an investment in the partnership, with the sponsor contributing the balance (Chadbourne \& Parke 2016b). The sponsor may also use back leveraged debt to finance the sponsor's capital contribution which is shown in Figure 4. 


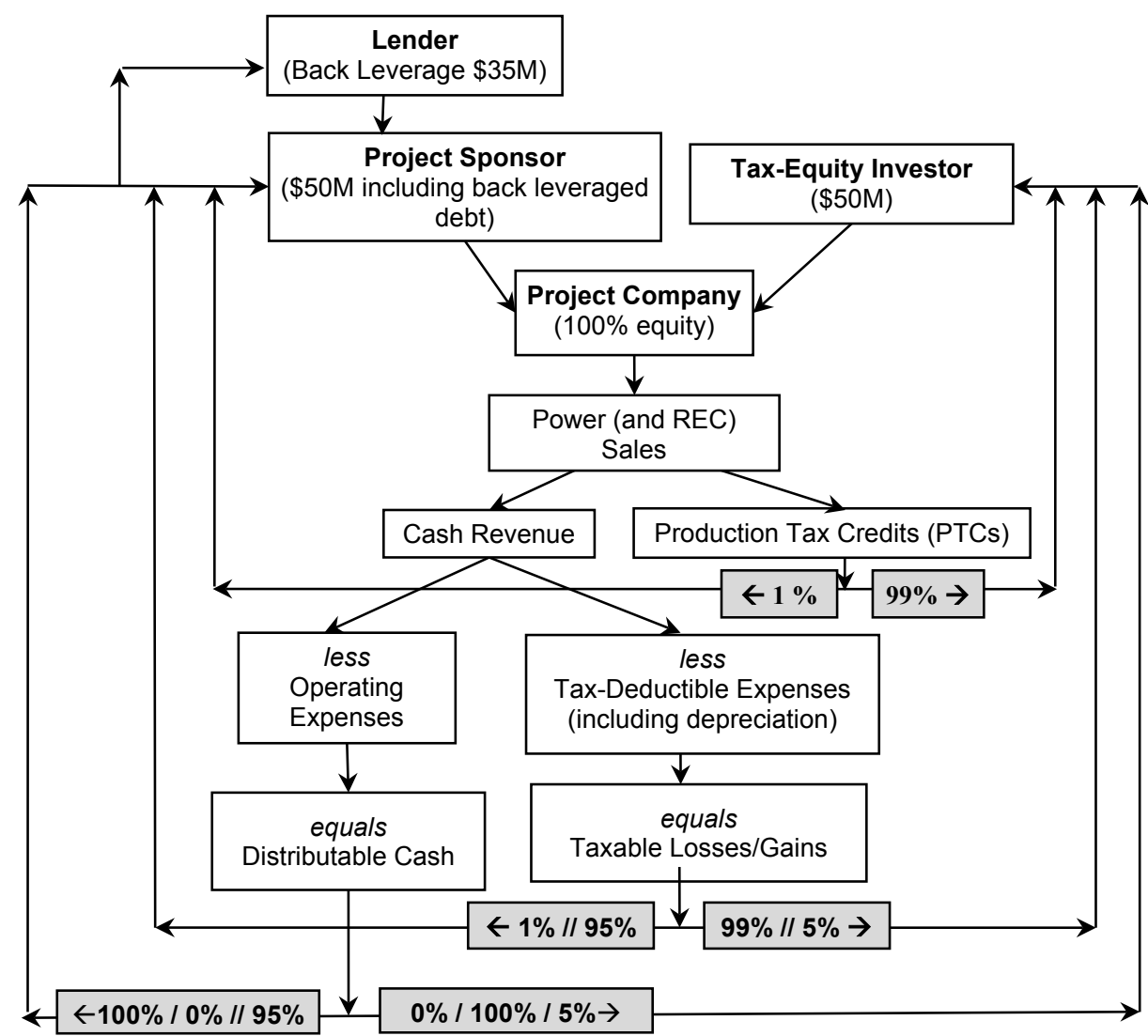

Figure 4. Hypothetical partnership flip structure for a $\$ 100$ million wind project

/= first flip point in transaction where distributions ratios are initially altered $/ /=$ second flip point in transaction where distribution ratios are again altered Source: Adapted from Feldman, Lowder, and Schwabe 2016 


\section{Corporate Purchasing and Procurement ${ }^{18}$}

PPAs are energy transaction contracts - usually long-term (20 years is common) - between electricity generation owners (sellers) and energy offtakers (buyers). A PPA stipulates the commercial terms at which energy sales will be transacted from the buyer of electricity to the seller, principally the price at which the offtaker will purchase the energy (usually expressed in kilowatt-hour [kWh] or megawatt-hour [MWh]) and the length of time during which it will make such purchases (the term). ${ }^{19}$

One of the principal benefits of a PPA is that it provides electricity generation owners with longterm, contractually-obligated energy sales mechanisms in which they earn revenue and investment returns. Financiers of wind projects will typically require that the sponsor has successfully negotiated a PPA from a creditworthy buyer before providing capital for the project. There are, however, cases in which wind farms have been constructed on a "merchant" basis (i.e., they are financed and built with a partial PPA or entirely without a PPA and must sell energy into the wholesale markets), and in these cases investors will typically demand a higher return for the risks associated with merchant projects (Wiser and Bolinger 2016).

Utilities have traditionally been the primary offtakers/buyers for electricity from wind PPAs, largely because of renewable portfolio standards (RPS) at the state level. The contribution of RPS purchasing to renewable energy growth, however, has declined in recent years, falling from $71 \%$ of builds in 2013 to $46 \%$ in 2015 (Barbose 2016). ${ }^{20}$ While compliance-oriented purchasing of renewables from utilities has been decreasing in recent years, purchases of renewable energy by corporations has been on the rise. For example, the Rocky Mountain Institute reports that all corporate renewable deals rose from $50 \mathrm{MW}$ in 2012 to a recent high of $3.25 \mathrm{GW}$ in 2015, which fell to $1.48 \mathrm{GW}$ in 2016 . Nearly $1.17 \mathrm{GW}$ of corporate purchases were completed in the first six months of 2017 (see Figure 5). ${ }^{21}$

\footnotetext{
${ }^{18}$ Unless specifically noted otherwise, this section was constructed from a variety of industry sources including the 2016 Corporate Renewables Conference, with discussion from Chester et al. (2016), Martin et al. (2016), Porter, Craft, and Jackson (2016), and Quan (2016).

${ }^{19}$ Other common PPA terms may include an energy price escalation rate, insurance requirements, in-term purchase options, stipulations for system repair and maintenance, and removal, among other terms.

${ }^{20}$ Compliance purchasing is still likely to play an important role in wind procurement, particularly as states increase their renewable portfolio standards requirements.

${ }^{21}$ Note that this figure includes some corporate procurement strategies not included here such as green power purchases and green tariffs. For more information on these sources see the forthcoming Heeter et al. report.
} 


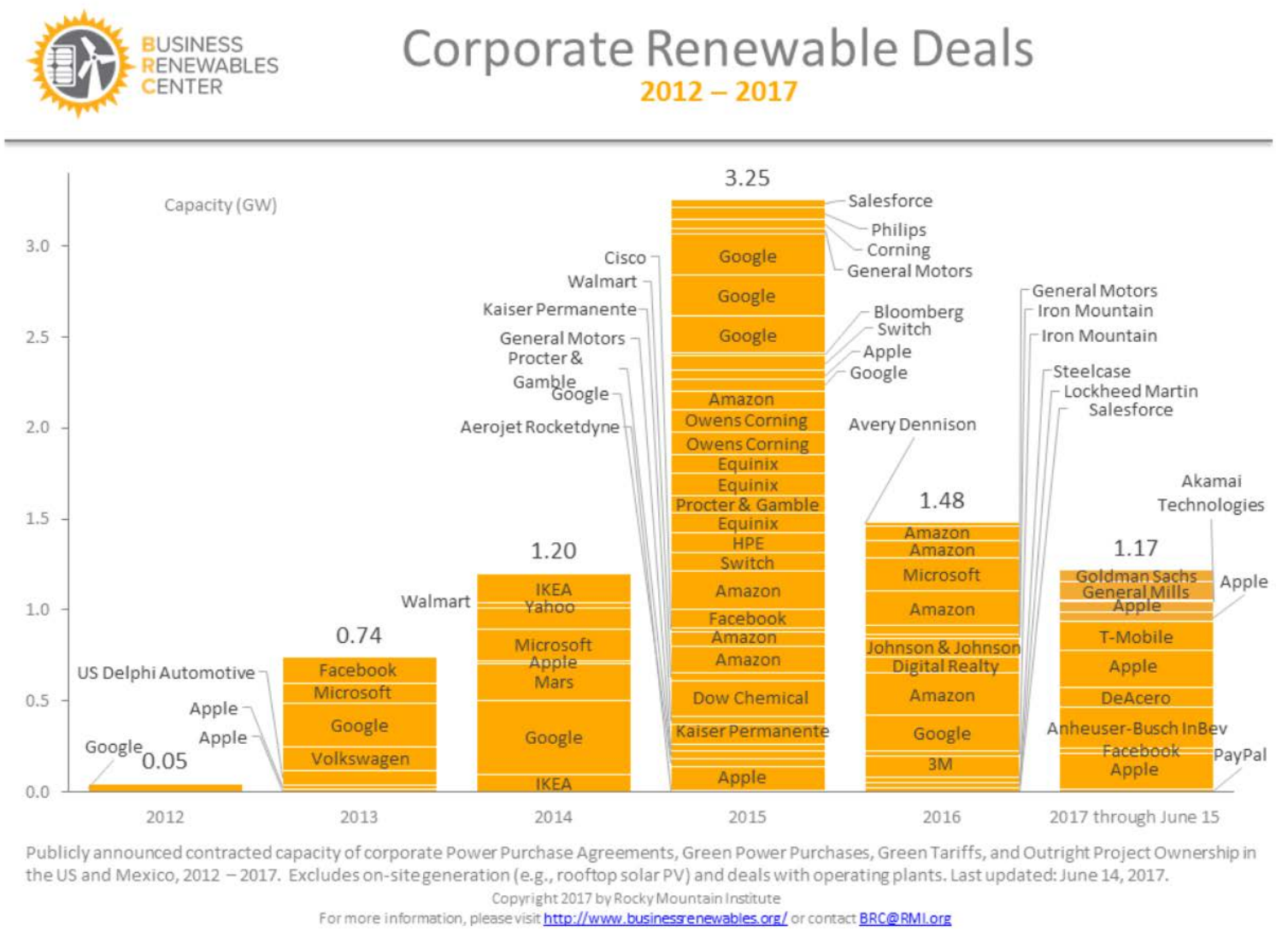

Figure 5. Corporate renewable deals: 2012-2017

Source: Rocky Mountain Institute 2017

The rise of corporate purchasing has allowed businesses to hedge their exposure to electricity price increases and meet sustainability goals while providing the wind industry with the critical revenue contracts that drive project financing. Corporate procurement has also offered additional opportunities for wind developers to attract new customers beyond just utilities. The following subsections, discuss the various contractual mechanisms by which corporations have sought to supplement their electricity purchases, primarily focused on those pertaining to wind-energy based procurement.

\subsection{Corporate Onsite Procurement}

Onsite procurement of energy may be an option for many commercial entities to meet their sustainability goals, limit exposure to energy price variability, benefit from federal tax incentives, and potentially return a profit. The majority of onsite renewable energy corporate procurement to date has used photovoltaic (PV) technology, with $13.8 \mathrm{GW}$ of non-residential 
distributed PV installed at the end of 2015 (SEIA and GTM Research 2016). ${ }^{22}$ Large companies have contributed significantly to this deployment.

However, corporations have installed other renewable technologies as well, including wind. Commercial and industrial projects represented $57 \%$ of the $28 \mathrm{MW}$ of distributed wind capacity installed in 2015 (Orrell and Foster 2016).

There are several advantages to procuring onsite renewable energy over offsite procurement. Companies have the potential to leverage underutilized assets, such as unused land or roofs for economic gain. Energy produced onsite is also potentially more valuable than energy procured offsite, as it is closer to energy load and does not necessarily need the use of transmission and distribution infrastructure. Onsite generation also provides a better hedge against rising electricity prices by simply reducing electricity consumption, rather than an imperfect hedge offered by a virtual PPA (discussed in the next section). Companies can also more directly incorporate these generating assets into their existing energy use to optimize performance.

However, the ability for companies to use onsite renewable energy is highly dependent on resource availability, available land, local interconnection policies, and other utility and government regulations. For large energy users such as datacenters, it is unlikely that companies will be able to source all of their energy from onsite generation, making it more difficult to meet aggressive sustainability targets. Additionally, some commercial customers may not have the ability to diversify their onsite renewable energy procurement options, potentially making them limited in their technology choices (Wrathall, Kramer, and Gerard 2016).

\subsection{Corporate Offsite Procurement}

Another way that corporations have secured renewable energy is by purchasing energy from a project that is located offsite or away from the corporate entity, utilizing variants of the PPA mechanism, and other procurement options.

Offsite procurement of renewable energy can mitigate many site-specific limitations that a company's physical land and building facilities may face in installing renewable energy systems. For example, a corporation may be located in an area with a comparatively poor wind resource quality or may have insufficient land, rooftops, or regulatory permission to build a renewable energy asset large enough to meet its energy needs (particularly if the corporation has aggressive energy goals). Additionally, a corporation with multiple facilities can pool its total energy needs and enjoy efficiencies from contracting with one or more offsite facilities. Offsite procurement can also allow corporations the ability to diversify their renewable energy procurement, potentially sourcing energy that is complementary to its needs. As an example, a corporation may contract with a wind facility to offset more of its nighttime and winter energy needs (when wind resources are typically the highest) and a solar facility to offset more of its daytime and summer energy needs.

Offsite corporate procurement can benefit renewable energy project developers because it can expand their potential customer base from utilities and onsite procurement. This is particularly

\footnotetext{
${ }^{22}$ The non-residential market includes mostly commercial and industrial customers, but also includes the government and nonprofit sectors.
} 
helpful in areas where utilities have already fulfilled their renewable energy procurement requirements or are not procuring more due to uncertainty surrounding future energy scenarios. Companies, in turn, benefit because they may be able make arrangements with developers on more favorable terms (Maloney 2016).

Because electricity generated by offsite facilities is not necessarily delivered to corporations' facilities, there are several different contracts employed that allow corporations the ability to benefit from the energy or other values produced by the systems. These include direct PPAs through virtual net metering; virtual PPAs (also known as contracts for differences); and contracting renewable energy through a company's electric service provider. ${ }^{23}$ Each procurement type will be discussed in detail below.

\subsubsection{Direct PPAs through Virtual Net Metering}

Under virtual net metering utility ratepayers can receive bill credits for some or all of the electricity generated by a qualifying offsite renewable energy project that is not directly interconnected to their electricity meter. A virtual-net-metered system may have many potential consumers and/or buyers of its energy including a corporate purchaser; likewise, consumers may have many virtual-net-metered systems from which to choose. However, virtual net metering is only available in select areas that have adopted legislation and/or regulation allowing its use; where available it is typically offered by the local regulated electric utility. As of October 2015, virtual net metering for wind projects was available to some corporations in six states and the District of Columbia (Farrell 2015). ${ }^{24}$

\subsubsection{Virtual PPAs}

Virtual PPAs (also known as "financial PPAs," "synthetic PPAs," "contracts for differences," or "fixed for floating swaps") do not involve the direct purchase of energy as do onsite PPA contracts or Direct PPAs with virtual net metering. Virtual PPAs, by contrast, require the ability to sell electricity into a wholesale electricity market. ${ }^{25}$ As of this writing, virtual PPAs are among the most preferred form of offsite corporate renewable energy procurement in the United States (Heeter et al., forthcoming).

In a virtual PPA the developer or sponsor does not actually deliver the power to the customer (i.e., the corporate purchaser). Instead, the corporation and developer agree to exchange the difference between the price at which the renewable energy is sold into the wholesale electricity market from the developer and the set contract price (or the virtual PPA rate) between the developer and corporate purchaser. If the renewable energy is sold into the wholesale market at a rate higher than the set contract price, the developer pays the corporate purchaser the difference in value; if on the other hand, the renewable energy is sold in the wholesale market at a lower price, the corporate purchaser pays the developer the difference in value. At the same time, the

\footnotetext{
${ }^{23}$ As noted previously, examples of other procurement options include green power programs offered by electricity suppliers and purchases of renewable energy certificates. For more information on these types of corporate procurement approaches see Heeter et al. (forthcoming).

${ }^{24}$ These states include Maine, Massachusetts, New Hampshire, Pennsylvania, Vermont, and Illinois (in which utilities can choose to offer virtual net metering). An additional four states offer virtual net metering to state and local governments, multi-tenant properties, or agricultural customers.

${ }^{25}$ Wholesale markets are responsible for serving two-thirds of the United States' electricity load (FERC 2017).
} 
corporation likely continues to purchase energy from its local utility (or utilities), ideally in the same power market. Figure 6 below summarizes these various transactions.

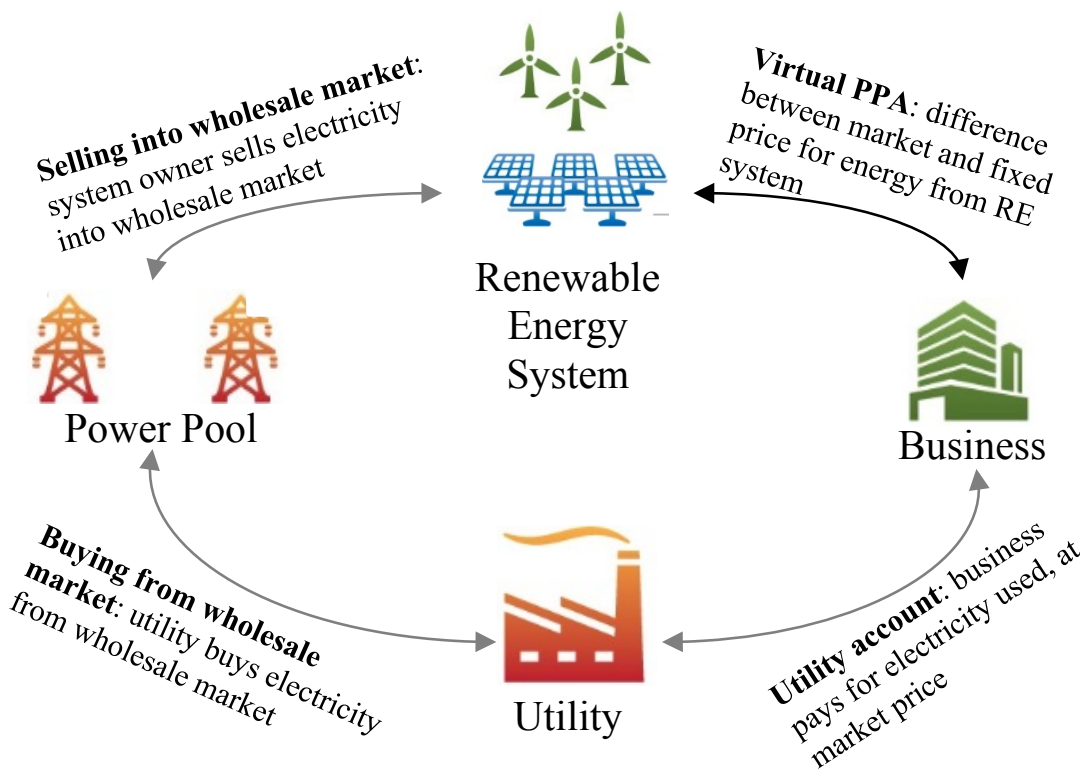

Figure 6. Summary of virtual PPA transactions

In executing a virtual PPA, both the developer and the corporate purchaser can be hedged to some extent against electricity market pricing. The developer of the renewable energy project will net the agreed-upon fixed price for energy through the contract of differences regardless of the price at which electricity was sold in the wholesale market. The corporate purchaser can also have some degree of a pricing hedge because the electricity it purchases from its service provider should be inversely correlated to the funds it either owes or receives from the developer through the contract for differences (assuming that the service provider rates are closely tied to wholesale market rates, as discussed below).

\subsubsection{Managing Location Risk in a Virtual PPA (Busbar vs. Hub)}

The ability for a business to use a virtual PPA as a hedge against its own electricity price depends on how correlated its electricity rates are to the rate at which the energy project sells its electricity. ${ }^{26}$ The price at which electricity is bought and sold in a wholesale market can depend on one's location within the market or electricity grid. In a contract for differences, the settling price of the contract can either be designated at the hub (regional location) or at the busbar (point of interconnection). If the busbar node (i.e., point of interconnection to the electricity grid) of the renewable energy project is different from that of the business then there is a potential difference in price that imposes a risk on the transaction, making the hedge less than fully protective. ${ }^{27}$ However, electricity can also be bought and sold at a power market's trading hub at a price which is calculated as the average price across all nodes within that area. Because these hubs

\footnotetext{
${ }^{26}$ When these prices are relatively correlated it is referred to as a "clean hedge;" the less correlated they are the "dirtier" the hedge.

${ }^{27}$ The difference between the location at which a project sells power and the location at which the contract price is set under the virtual PPA is called the "basis risk."
} 
cover several nodes they can be less volatile and more liquid (as more trading occurs at a hub than a specific node). Buying and selling at a hub incurs more costs because the electricity has to be delivered, or "wheeled," to the hub through contracts called financial transmission rates (FTRs). FTRs are another type of hedge, representing the difference between the price at the hub and the price at the node. FTRs are offered by many financial entities and utilities.

Corporations often prefer the settling price to be at the hub because there is less "basis risk"risk that some corporations think is better mitigated and managed by a developer. Developers, however, usually prefer the contract to be settled at the busbar because there are fewer costs and less complexity. ${ }^{28}$ Further, some developers think that settling the price at the busbar provides companies the opportunity to make more money because they do not have to incur wheeling costs. In the end it comes down to the preference of the corporation between financial upside and risk as well as its experience with these types of contracting mechanisms. In some instances, corporations have signed virtual PPAs for projects in regions in which they have no facilities; in these transactions there is greater basis risk (though likely some level of energy price hedge), but the project may offer a better return and a larger offset of a corporation's electricity use (Chadbourne \& Parke 2016a).

Bundling electricity load or renewable energy projects across a wider area can also diversify individual nodal electricity risk and create opportunities for corporations that do not own real estate and therefore are not as strongly tied to a particular location.

\subsubsection{Sleeved PPAs}

In some regulated states corporations may not have access to a wholesale market that prevents the use of a Virtual PPA. Additionally, some corporations may be reluctant to take on any sort of basis risk as described previously in the Virtual PPA model. Projects and developers have addressed these issues by contracting in a three-way deal with a customer's electricity provider, in what's known as a "utility green tariff," "sleeved PPA," or "back-to-back PPA."

In a sleeved PPA transaction the electricity service provider agrees to purchase the electricity from a renewable energy project through a PPA between the developer and electricity service provider, and the corporation in turn agrees to purchase that electricity from the utility through a matching PPA between the utility and corporate purchaser. Sleeved PPAs can offer benefits for all parties, as shown in the following examples: electricity service providers lock in energy and load from customers (avoiding stranded assets and declining customer usage); developers often have an easier time financing the project with the typically strong credit profile of a utility instead of corporation; and corporations lock in an electricity price hedge without the basis risk from their existing electric utility with which they have a long-standing relationship.

Sleeved PPAs are not without their drawbacks. Having multiple parties involved in back-to-back contracts - particularly if one of them is a regulated entity - means significant time, energy, and money is spent setting up transactions. Additionally, sleeved PPAs typically require state public utility commission approval and the regulated utility will usually charge fees on top of the PPA.

\footnotetext{
${ }^{28}$ In addition to the cost of arranging and executing the FTR, developers may have to set aside a cash reserve to satisfy contract terms. These additional requirements make it more difficult for the developer to finance the project.
} 


\section{Cost-of-Capital Impacts}

The cost of capital can influence a wind project's overall cost of energy and accordingly its cost competitiveness. It is therefore critical for developers to have a comprehensive understanding about not only the availability of capital, but also about how variations in possible financing rates will impact their projects' economic cost profile. Developers often won't have fully-secured financing rates until near the financial close of the project, which is among the latter milestones of the development process. Thus developers will use best estimates and forecasts to estimate possible financing costs and the corresponding impact on their projects' overall economics. The developer will typically identify the point at which the financing rates are low enough to enable the project to be economically viable and the high-cost threshold where the project may no longer be competitive.

This section demonstrates how low- and high-cost financing scenarios can impact the cost of a wind energy project using a simplified LCOE analysis. ${ }^{29} \mathrm{LCOE}$ is an economic measure that is calculated by summing the entirety of the project's lifetime costs (including upfront capital costs, ongoing O\&M expenditures, and financing rates among others expenses), discounting to present value terms, and then dividing by the expected lifetime energy production of the wind plant. The output of this calculation is a cost per unit of energy, typically expressed either in cents per $\mathrm{kWh}$ or dollars per MWh. LCOE can be used in comparison to the price that a developer expects to receive for the energy generated by the system, which could be the market price, the negotiated PPA price, the applicable green tariff rate, or another revenue source. A calculated LCOE at or below the comparative energy price would indicate the project is competitive economically, while an LCOE at or above the comparative price would likely require additional actions to lower the LCOE of the project through decreasing costs or increasing energy production.

To illustrate the effects of financing rates on the LCOE, the authors ran an analysis in NREL's System Advisor Model (SAM), a performance and financial model that allows users to provide a number of project-specific input parameters to estimate the LCOE along with several other outputs (NREL 2017). The authors employed a simplistic methodology that minimizes the number of non-financial parameters required, including capital costs (equipment), capacity factor (i.e., energy production), annual O\&M expenses, and annual inflation assumptions. ${ }^{30}$ The specific values of these variables were based on NREL's comprehensive wind cost analysis report “2015 Cost of Energy Review” (Moné et al. 2017).

In this analysis, two financing scenarios are assumed representing a high- and low-cost financing case while the non-financial parameters are held constant. The input values for the financial parameters are shown in Table 2. In the Higher-Cost Financing Scenario, sponsor equity and tax

\footnotetext{
${ }_{29}$ Other recent wind energy LCOE analyses include Cory and Schwabe (2009), which present multiple-variable sensitivity analyses, and the International Energy Agency (IEA) Wind Working Group Task 26, which looks at international variations in the cost of wind energy (Cory and Schwabe 2016, IEA 2016). The investment bank Lazard also produces an annual report that compares LCOE across multiple energy generation technologies as well as various cost sensitivities (Lazard 2016).

${ }^{30}$ The following values were used for the non-financial parameters representing the "Base-Case" project in the cost of energy review: $\$ 1,690 / \mathrm{kW}$ capital costs, a net capacity factor of $39.9 \%$ based on a P50 estimates, annual O\&M costs at $\$ 51 / \mathrm{kW}$-yr, $2 \%$ inflation and escalation rates, and a 20 -year project, assuming the use of the $\$ 23 / \mathrm{MWh}$ PTC for the first ten years of a project's operation (equating to the PTC value in 2016 for a project that began construction in 2016 to qualify for the full value PTC).
} 
equity IRR are valued at $12 \%$ and $8 \%$, respectively; the interest rate on debt is offered at $5 \%$ with a 15 -year repayment term, and debt comprises $35 \%$ of the project's capital. ${ }^{31}$ In the LowerCost Financing Scenario, sponsor equity and tax equity IRR are $10 \%$ and $7 \%$, respectively; interest rate on debt is $4.5 \%$ with an 18 -year repayment term, and debt comprises $40 \%$ of the project's total capital. The use of the PTC is also assumed in both cases.

These financing cost scenarios illustrate only two of any number of possible financing permutations. In general, however, the Higher- and Lower-Cost Financing Scenarios represent plausible variations in both the cost and structure of the project. The Lower-Cost financing scenarios generally reflect historic lows in pricing, particularly for the tax equity rates (Chadbourne \& Parke 2007; Harper, Karcher, and Bolinger 2007), while the Higher-Cost Financing Scenario is closer to project pricing in 2016 (Shurey 2016; Chadbourne \& Parke 2015).

As shown in Table 2, the SAM model yields an LCOE of $\$ 51$ per MWh for the Higher-Cost Financing Scenario. Under the Lower-Cost Financing Scenario, the SAM model yields a lower LCOE of $\$ 42$ per MWh. This analysis reveals an LCOE premium of approximately $\$ 9 / \mathrm{MWh}$ for the Higher-Cost Financing Scenario relative to the Lower-Cost Financing Scenario. ${ }^{32}$

Table 2. LCOE Comparison of a Higher Cost and Lower Cost Financing Scenario

\begin{tabular}{|l|c|c|}
\hline \multicolumn{1}{|c|}{ SAM Financial Model Inputs } & $\begin{array}{c}\text { Higher-Cost Financing } \\
\text { Scenario }\end{array}$ & $\begin{array}{c}\text { Lower-Cost Financing } \\
\text { Scenario }\end{array}$ \\
\hline Sponsor Equity IRR & $12 \%$ & $10 \%$ \\
\hline Tax Equity IRR & $8 \%$ & $7 \%$ \\
\hline Debt Interest Rate & $5 \%$ & $4.5 \%$ \\
\hline Loan Term (years) & 15 & 18 \\
\hline Debt Percentage & $35 \%$ & $40 \%$ \\
\hline Resulting Nominal LCOE (\$/MWh) & $\mathbf{\$ 5 1}$ & $\mathbf{\$ 4 2}$ \\
\hline
\end{tabular}

From the perspective of the project developer, these calculated LCOEs of $\$ 51 / \mathrm{MWh}$ and $\$ 42 / \mathrm{MWh}$ would then be compared to the expected energy price of the project, whether that be an executed PPA price, a wholesale energy price, a green tariff rate, or other revenue metric. If the project's developer had secured an energy price that exceeds the LCOE from either the Higher- or Lower-Cost Financing Scenarios, then the project will likely generate sufficient revenue to meet its ongoing maintenance, debt payments, reserve accounts, and investor returns. This case is illustrated by the black gradient bar shown in Figure 7. The more the energy price exceeds the LCOE, the larger the potential revenue surplus and thus the more profit the project may earn.

\footnotetext{
${ }^{31}$ SAM's financial calculations model debt that is secured at the project level. The debt term assumes that a constant amortization period is utilized rather than the mini-perm structure described previously, which requires a balloon payment before the end of the term.

${ }^{32}$ Importantly, this LCOE range includes the effect of both economy-wide conditions, such as the overall supply of debt and equity and investor's appetite for risk, as well as project-specific risk factors. A project developer may be able to address the project-specific risk factors but usually not those attributable to market-wide forces, such as overall investor sentiment and benchmark financing rates. As an example, Bolinger (2017) finds a comparatively smaller LCOE reduction opportunity of around $\$ 2 / \mathrm{MWh}$ to $\$ 2.5 / \mathrm{MWh}$ when analyzing risks specifically associated with energy production uncertainty (Bolinger 2017).
} 
Conversely, if a developer has secured an energy price that is below the Lower-Cost Financing Scenario's LCOE, then the project will not likely generate sufficient revenue to both meet its ongoing cost obligations (i.e., debt payments, O\&M, reserve accounts, etc.) as well as provide the modeled return to the investor. This case is depicted with the red gradient bar in Figure 7. In this case, the sponsor or investor may willingly accept a lower return, seek cost reductions elsewhere (e.g., through lower-cost equipment), or delay project financing until market conditions improve (e.g., if benchmark interest rates fall). An energy price that falls between the two financing costs scenarios $(\$ 51 / \mathrm{MWh}$ versus $\$ 42 / \mathrm{MWh}$ - showed in the dashed area in Figure 7) can likely proceed if the developer is able to secure financing at the rates used in the LowerCost Scenario. However, if rates lie at the Higher-Cost Financing Scenario, the developer may seek similar measures to close the revenue gap.

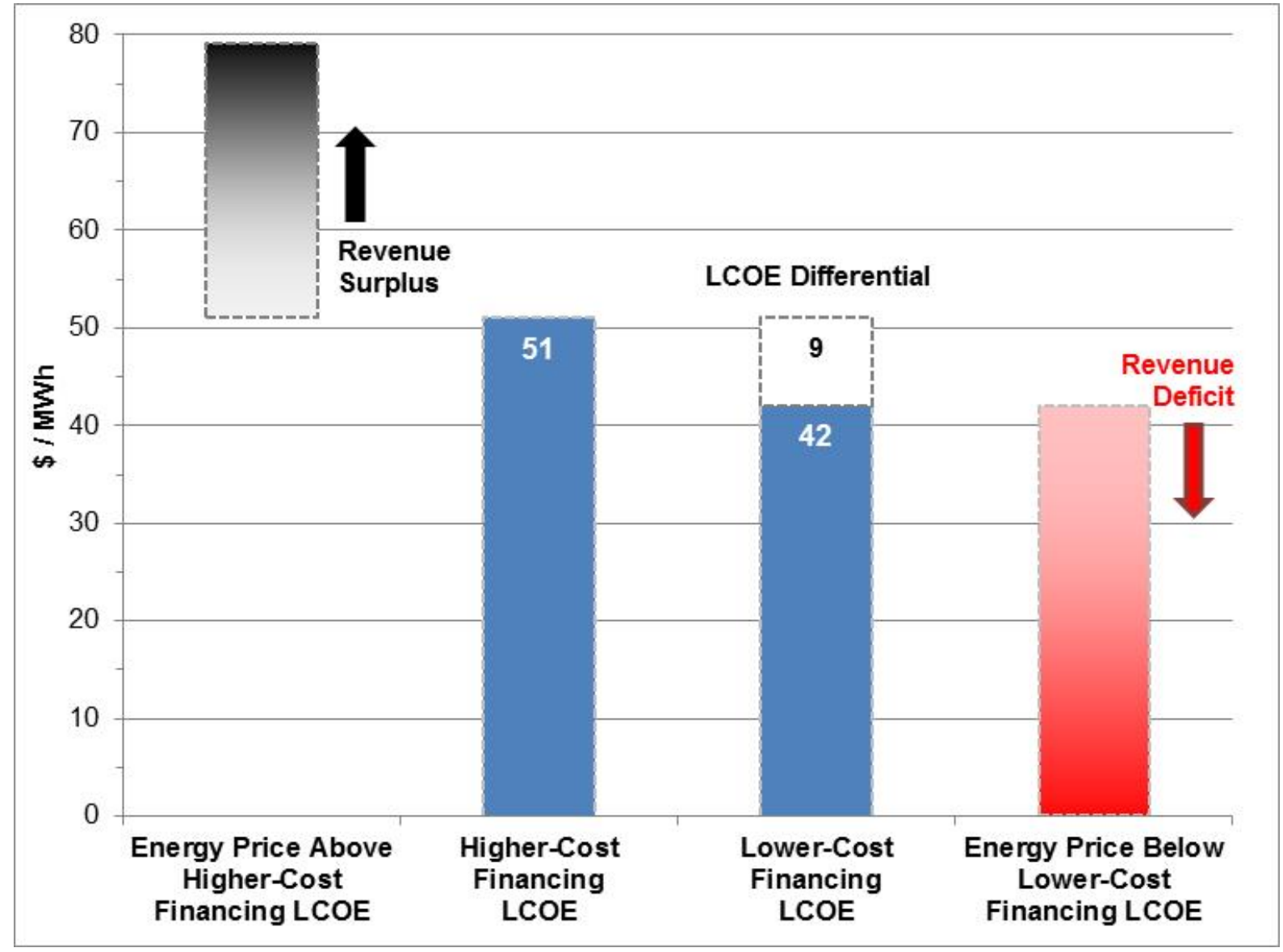

Figure 7. Comparison of financing scenarios to energy prices

There are several reasons why the financing costs for a wind project can vary from one project to the next, as well as over time. First, some financing cost variations are attributable to macroeconomic forces and reflect the changing benchmark interest rates or the market's risk tolerance. Second, financing rates are also driven by the unique characteristics of the project itself. For example investors will look at unique project-specific factors such as the type of the specific turbine technology utilized, its performance history in the marketplace, the commercial experience of the project developer to deliver projects on time and budget, and the specific elements within the deal to mitigate and control for risks and uncertainty. Some investors will 
simply be more comfortable with accepting certain types of project risks while others investors will not. Finally, other hard to quantify or subjective factors also contribute towards the overall financing costs of a project. As an example of this, the history and relationship between the firms is also an important consideration: commercial lending can be a "relationship-based" business and firms may be willing to offer preferred pricing to partners who have a long, profitable, or strategic banking partnership. In reality, many if not all of these factors contributes in varying degrees to the overall investment costs for a project. 


\section{Conclusion}

As discussed in this report, investment in wind energy in the United States has averaged nearly $\$ 13.6$ billion on annual basis since 2006 with more than $\$ 140$ billion invested cumulatively over that period (BNEF 2017). The investment activity demonstrates the persistent appeal of wind energy and its significant role in the overall market for electricity generation in the United States. The development and financing of wind projects, however, remains a complex and expensive process that, because of the capital requirements of wind energy, can influence the economic competitiveness of wind energy compared to other generation sources that are less capital intensive.

Looking ahead, the near-term outlook for wind energy reported previously suggests a continued need for capital availability at levels consistent with deployment seen in 2015 and 2016 (Wiser and Bolinger 2016). The market has shown the capacity to finance projects at this level using current mechanisms at economically viable rates; however, increased deployment could necessitate new sources of capital. Broad changes to the financial industry-such as the possibility of major corporate tax reform, the currently scheduled phase out of the PTC and ITC for wind, and, specifically, a change in the role of tax equity-could fundamentally reshape the predominant mechanism for wind energy investment. It is possible that financing practices may need to evolve, while the growing body of wind energy deployment and operational experiences could help to attract new market participants. Whatever the future holds, it is likely that financing will continue to impact a project's overall economic competitiveness, and that efforts to open up more capital sources and reduce financing costs will continue. 


\section{References}

AWEA (American Wind Energy Association). 2017. U.S. Wind Industry Fourth Quarter 2016 Market Report. Washington, D.C.: American Wind Energy

Association. http://awea.files.cmsplus.com/FileDownloads/pdfs/4Q2016\%20AWEA\%20Market\%20Report\%20Public\%20 Version.pdf.

Bailey, Bruce. 2016. "Wind Farm Underperformance: Are Haircuts Still Apropos?” AWS Truepower blog, February 22. https://www.awstruepower.com/wind-farmunderperformance-are-haircuts-still-apropos/.

Barbose, Galen. 2016. U.S. Renewables Portfolio Standards 2016 Annual Status Report. Berkeley, CA: Lawrence Berkeley National Laboratory. https://emp.lbl.gov/sites/all/files/lbnl-1005057.pdf.

BNEF. (Bloomberg New Energy Finance). 2017. “Q4 2016 Clean Energy Factpack.” January 2017.

Bolinger, Mark. 2014. An Analysis of the Costs, Benefits, and Implications of Different Approaches to Capturing the Value of Renewable Energy Tax Incentives. Berkeley, CA: Lawrence Berkeley National Laboratory. https://emp.lbl.gov/sites/all/files/lbnl$\underline{6610 \mathrm{e} 0 . p d f}$.

- 2017. Bookending the Opportunity to Lower Wind's LCOE by Reducing the Uncertainty Surrounding Annual Energy Production. Berkeley, CA: Lawrence Berkeley National Laboratory. https://emp.lbl.gov/sites/default/files/lbnl_a2e_pruf_bookending_final.pdf.

Burns \& McDonnell. 2009. G775 Generation Interconnection System Impact Study. Prepared for the Midwest Independent Transmission System Operator. Carmel, Indiana: Midwest Independent Transmission System

Operator. https://www.misoenergy.org/Library/Repository/Study/Generator\%20Interconn ection/GI-G775-SIS_Report.pdf.

Business Dictionary. 2017. "Pro-forma." Accessed July

12. http://www.businessdictionary.com/definition/pro-forma.html.

Carlin, Clint, and Jason Weaver. 2015. Alternative Energy Derivative and Hedge Accounting. New York:

Deloitte. https://www2.deloitte.com/content/dam/Deloitte/us/Documents/energyresources/us-er-alternative-energy-derivative-hedge-accounting.pdf.

Chadbourne \& Parke 2014. "Current Issues in Holdco Loans." Project Finance Newswire, November. https://www.chadbourne.com/Current-Issues-in-HoldcoLoans_projectfinance.

—. 2007. "The Tax Equity Market." Project Finance Newswire, April. http://www.nortonrosefulbright.com/files/chadbourne/publications/pfn0407.pdf. 
2015. "Cost of Capital: 2015 Outlook." Project Finance Newswire,

February. http://www.chadbourne.com/Cost-of-Capital-2015-Outlook-02-18-

2015 projectfinance.

- 2016a. "Corporate PPAs." Project Finance Newswire,

August. https://www.chadbourne.com/corporate-PPAs-project-finance-august-2016.

- 2016b. "Wind Tax Equity Market Update." Project Finance Newswire,

December. https://www.chadbourne.com/Wind-Tax-Equity-Market-project-finance-

december-2016.

—. 2017. "Cost of Capital: 2017 Outlook." Project Finance Newswire,

February. https://www.chadbourne.com/cost-of-capital-2017-outlook-project-finance-

february-2017.

Chester, Jeff, Jam Attari, Sanjay Bhasin, Cynthia Christensen, Andrew Dickson, and Steve Vavrik. 2016. "Renewable Developers' Perspectives-Understanding their Needs and Constraints." Presented at the Corporate Renewables Conference, Washington, D.C., September 27-28.

Clifton, Andrew, Aaron Smith, and Michael Fields. 2016. Wind Plant Preconstruction Energy Estimates: Current Practice and Opportunities. NREL/TP-5000-64735. Golden, CO: National Renewable Energy Laboratory. http://www.nrel.gov/docs/fy16osti/64735.pdf.

Cory, Karlynn, and Paul Schwabe. 2009. Wind Levelized Cost of Energy: A Comparison of Technical and Financing Input Variables. NREL/TP-6A2-46671. Golden, CO: National Renewable Energy Laboratory. http://www.nrel.gov/docs/fy10osti/46671.pdf.

DOE (U.S. Department of Energy). 2017. “Loan Programs Office.” Accessed February. https://energy.gov/lpo/loan-programs-office.

Dworkin, Meyer C., and Monica Holland. 2014. "Recent Trends in U.S. Term Loans B.” In Lending \& Secured Finance 2014, $2^{\text {nd }}$ ed., edited by Thomas Mellor, 26-30. London: Global Legal Group

Ltd. https://www.davispolk.com/sites/default/files/Recent.Trends.in_US .Term _Loan . B.pdf.

EERE (U.S. Department of Energy Office of Energy Efficiency and Renewable Energy). 2017. "Atmosphere to Electrons: Performance, Risk, Uncertainty, and Finance (PRUF)." Accessed July 13. https://a2e.energy.gov/about/pruf.

Eliason, John A. 2012. "Investing in Alternative Energy? Consider the Passive Activity Loss Rule." Renewable Energy World, December 19. http://www.renewableenergyworld.com/articles/2012/12/investing-in-alternativeenergy-consider-the-passive-activity-loss-rule.html. 
Farrell, John. 2015. "Updated: States Supporting Virtual Net Metering." Institute for Local SelfReliance blog, November 4. https://ilsr.org/rule/net-metering/updated-states-supportingvirtual-net-metering/.

Feldman, David, and Mark Bolinger. 2016. On the Path to SunShot: Emerging Opportunities and Challenges in Financing Solar. NREL/TP-6A20-65638, LBNL-1004372. Golden, CO: National Renewable Energy Laboratory and Berkeley, CA: Lawrence Berkeley National Laboratory. http://www.nrel.gov/docs/fy16osti/65638.pdf.

Feldman, David, Daniel Boff, and Robert Margolis. 2016. "Q2/Q3 2016 Solar Industry Update." Presentation, October 11. NREL/PR-6A20-67246. Washington, D.C.: U.S. Department of Energy. http://www.nrel.gov/docs/fy17osti/67246.pdf.

Feldman, David, Travis Lowder, and Paul Schwabe. 2016. PV Project Finance in the United States, 2016. NREL/BR-6A20-66991. Golden, CO: National Renewable Energy Laboratory. http://www.nrel.gov/docs/fy16osti/66991.pdf.

FERC (Federal Energy Regulatory Commission). 2017. "Electric Power Markets: National Overview." Last modified April 13. https://www.ferc.gov/market-oversight/mktelectric/overview.asp.

Fitch. 2014. "US Wind Power Production Underperformance May Continue." News release, November 14. https://www.fitchratings.com/gws/en/fitchwire/fitchwirearticle/US-WindPower?pr id=924195.

- 2016. Rating Criteria for Onshore Wind Farm Projects Effective From 14 May 2015 to 31 March 2016. New York: Fitch Ratings.

Goldman Sachs. 2014. Interactive Guide to the Capital Markets. February. http://www.goldmansachs.com/s/interactive-guide-to-capital-markets/.

Groobey, Chris, John Pierce, Michael Faber, and Greg Broome. 2010. Project Finance Primer for Renewable Energy and Clean Tech Projects. Palo Alto, CA: Wilson Sonsini Goodrich and Rosati, https://www.wsgr.com/PDFSearch/ctp_guide.pdf.

Harper, John P., Matthew D. Karcher, and Mark Bolinger. 2007. Wind Project Financing Structures: A Review and Comparative Analysis. Berkeley, CA: Lawrence Berkeley National Laboratory. https://emp.lbl.gov/sites/all/files/report-lbnl-63434.pdf.

Heeter, Jenny, Jeff Cook, and Lori Bird. 2017. Evaluating Models and Opportunities for Corporate Purchases from Off-site Utility Scale Solar. National Renewable Energy Laboratory, forthcoming.

Investopedia. 2016. "Pro-forma." Accessed May. http://www.investopedia.com/terms/p/proforma.asp.

IRS (Internal Revenue Service). 2013. "Private Letter Ruling 201311003.” March 15. https://www.irs.gov/pub/irs-wd/1311003.pdf. 
- 2016. Beginning of Construction for Sections 45 and 48. Notice 2016-

31. https://www.irs.gov/pub/irs-drop/n-16-31.pdf.

- 2017a. Beginning of Construction for Sections 45 and 48. Notice 2017-

4. https://www.irs.gov/irb/2017-04_IRB/ar10.html

—. 2017b. Publication 946: How to Depreciate Property. Washington, D.C.: Internal Revenue Service, February. https://www.irs.gov/uac/about-publication-946.

Lazard. 2016. "Levelized Cost of Energy Analysis 10.0." Insights blog, Lazard, December 15. https://www.lazard.com/perspective/levelized-cost-of-energy-analysis-100/.

Lee, April, and David Darling. 2016. "Wind Adds the Most Electric Generation Capacity in 2015, Followed By Natural Gas and Solar." Today in Energy, Energy Information Administration, March 23. https://www.eia.gov/todayinenergy/detail.php?id=25492.

Lowder, Travis, and Michael Mendelsohn. 2013. The Potential of Securitization in Solar PV Finance. NREL/TP-6A20-60230. Golden, CO: National Renewable Energy Laboratory. http://www.nrel.gov/docs/fy14osti/60230.pdf.

Lowder, Travis, Paul Schwabe, Ella Zhou, and Douglas J. Arent. 2015. Historical and Current U.S. Strategies for Boosting Distributed Generation. NREL/TP-6A50-64843. Golden, CO: National Renewable Energy Laboratory. http://www.nrel.gov/docs/fy16osti/64843.pdf.

Maloney, Peter. 2016. "Mutual Needs, Mutual Challenges: How Corporate PPAs are Remaking the Renewables Sector." Utility Dive, September

1. http://www.utilitydive.com/news/mutual-needs-mutual-challenges-how-corporateppas-are-remaking-the-renewa/425551/.

Martin, Keith, J. Renée Morin, Ted Romaine, Jacob Susman, and Anthony Davis. 2016. "The Corporate Renewable Project Landscape 2016 and Beyond." Presented at the Corporate Renewables Conference, Washington, D.C., September 27-28.

Martin, Keith. 2011. "Developer Fees." Project Finance Newswire, Chadbourne \& Parke, March 31. http://www.chadbourne.com/In Other News Developer-Fees-03-31-

2011 Projectfinance.

Moné, Christopher, Maureen Hand, Mark Bolinger, Joseph Rand, Donna Heimiller, and Jonathan Ho. 2017. 2015 Cost of Wind Energy Review. Golden, CO: National Renewable Energy Laboratory and Berkeley CA: Lawrence Berkeley National Laboratory. http://www.nrel.gov/docs/fy17osti/66861.pdf.

NAW (North America Windpower). 2014. “Are Fitch Ratings' Claims About Wind Farm Underperformance Unfounded?” NAW blog, November 20. http://nawindpower.com/arefitch-ratings-claims-about-wind-farm-underperformance-unfounded. 
Novogradac. 2016. "Summary Chart of Renewable Energy Provisions' Expiration

Dates.” https://www.novoco.com/sites/default/files/atoms/files/path_act_summary_chart renewable energy expiration dates_050216.pdf.

NREL (National Renewable Energy Laboratory). 2017. “System Advisor Model.” Accessed July 10. https://sam.nrel.gov/.

Orrell, Alice C., and Nikolas F. Foster. 2016. 2015 Distributed Wind Market Report. Richland, WA: Pacific Northwest National Laboratory. https://energy.gov/sites/prod/files/2016/08/f33/2015-Distributed-WindMarket-Report-08162016 0.pdf.

Porter, Mark, Jeff Craft, and Kevin Jackson. 2016. "The Accounting Implications of Deal Structures." Presented at the Corporate Renewables Conference, Washington, D.C., September 27-28.

Quan, Cindy. 2016. “Today's Corporate Renewable Market.” Presented at the Corporate Renewables Conference, Washington, D.C., September 27-28.

Ray, Suparna. 2017. "U.S. Electric Generating Capacity Increase in 2016 Was Largest Net Change Since 2011." Today in Energy, Energy Information Administration, February 27. http://www.eia.gov/todayinenergy/detail.php?id=30112.

RMI (Rocky Mountain Institute). 2017. “BRC Deal Tracker.” Accessed July 10. http://www.businessrenewables.org/corporate-transactions/.

Schwabe, Paul. 2010. "Peeling the Onion: The Layers of Capital Structures." National Renewable Energy Laboratory Market Insight blog, October 25. https://financere.nrel.gov/finance/content/peeling-onion-layers-capital-structures.

SEIA and GTM Research (Solar Energy Industries Association and GTM Research). 2016. U.S. Solar Market Insight: 2015 Year-in-Review. Washington, D.C.: Solar Energy Industries Association.

Shanahan, Matt, John Wisniewski, and Greg Andiorio. 2017. U.S. Federal Corporate Tax Reform Potential Impact on U.S. Renewable Financing. Chicago: Marathon Capital. http://www.marathon-cap.com/docs/default-source/white-papers/marathoncapital-white-paper---u-s-federal-corporate-tax-reform.pdf?sfvrsn=4.

Shurey, D. 2016. H1 2016 North America Wind Market Outlook. New York: Bloomberg New Energy Finance.

Springer, Robert. 2013. A Framework for Project Development in the Renewable Energy Sector. NREL/TP-7A40-57963. Golden, CO: National Renewable Energy Laboratory. http://www.nrel.gov/docs/fy13osti/57963.pdf. 
Tawney, Letha, and Josh Ryor. 2014. "How Green Tariffs Can Benefit Utilities and Consumers." World Resources Institute blog, January 23. http://www.wri.org/blog/2014/01/howgreen-tariffs-can-benefit-utilities-and-consumers.

Taylor, Chris, and Sara Parsons. 2008. "An Overview of the Wind Power Project Development Process and Siting Considerations." Horizon Wind Energy and PPM Energy. http://www.energy.ca.gov/windguidelines/training/2008-0304 workshop/presentations/PARSONS_WIND_INDUSTRY_PROJECT\%20PERMITTI NG.PDF.

US Bank. 2016. "The Basics: Tax Credit Syndications.” Accessed October. https://www.usbank.com/commercial-business/tax-credit-financing/tax-creditsyndication.html.

Vestas. n.d. Key Aspects in Developing a Wind Power Project. Aarhus, Denmark: Vestas Wind Systems. https://www1.eere.energy.gov/tribalenergy/guide/pdfs/developingwindpower.pdf

We Energies. n.d. Developing and Constructing Wind Energy. Milwaukee, WI: We Energies. https://www.we-energies.com/environmental/windenergy.pdf.

Wiser, Ryan H., and Mark Bolinger. 2016. 2015 Wind Technologies Market Report. LBNL1005951. Berkeley, CA: Lawrence Berkeley National Laboratory. https://emp.lbl.gov/publications/2015-wind-technologies-market-report.

Wrathall, Jim, Merrill L. Kramer, and Morgan Gerard. 2016. "Keys to Success for Corporate Procurement Transactions." October 11. http://www.mondaq.com/unitedstates/x/534248/Renewables/THE+FUTURE+OF+EL ECTRICITY+MARKETS. 